Illinois State University

ISU ReD: Research and eData

Theses and Dissertations

5-23-2019

\title{
Examining the relationship between media consumption and Kenya's political culture
}

Gilbert Kipkoech

Illinois State University, kipkoechgilbert55@gmail.com

Follow this and additional works at: https://ir.library.illinoisstate.edu/etd

Part of the Communication Commons

\section{Recommended Citation}

Kipkoech, Gilbert, "Examining the relationship between media consumption and Kenya's political culture" (2019). Theses and Dissertations. 1135.

https://ir.library.illinoisstate.edu/etd/1135

This Thesis and Dissertation is brought to you for free and open access by ISU ReD: Research and eData. It has been accepted for inclusion in Theses and Dissertations by an authorized administrator of ISU ReD: Research and eData. For more information, please contact ISUReD@ilstu.edu. 


\section{EXAMINING THE RELATIONSHIP BETWEEN MEDIA CONSUMPTION AND KENYA'S \\ POLITICAL CULTURE}

\section{GILBERT KIPKOECH}

\section{Pages}

Using data collected from 206 participants, this country-specific study examines the relationship between media consumption and Kenya's political culture. Political scientists and communicators contend that political culture encompasses several aspects. In this study, only four aspects of a country's political orientations (culture) and its relationship with the media are examined (a) Political participation, (b) political trust, (c) patriotism, and (d) inter-ethnic attitudes. Drawing on past research, the study establishes a link between media use and political attitudes and behaviors of the Kenyan people, operationalized in the study as the political culture. While the literature is divided on whether the media is a mobilizing force that influences people's political attitudes and behaviors positively or negatively, this study shows that online media consumption is negatively correlated with political interest and participation, and TV viewing is also negatively correlated with political participation. Drawings have been made on these findings as well its theoretical, methodological, and practical implications.

KEYWORDS: Political culture, Media, Kenya, Correlations 
EXAMINING THE RELATIONSHIP BETWEEN MEDIA CONSUMPTION AND KENYA'S

POLITICAL CULTURE

\section{GILBERT KIPKOECH}

A Thesis Submitted in Partial

Fulfillment of the Requirements

for the Degree of

MASTER OF SCIENCE

School of Communication

ILLINOIS STATE UNIVERSITY

2019 
(C) 2019 Gilbert Kipkoech 


\title{
EXAMINING THE RELATIONSHIP BETWEEN MEDIA CONSUMPTION AND KENYA'S \\ POLITICAL CULTURE
}

\author{
GILBERT KIPKOECH
}

COMMITTEE MEMBERS:

John Baldwin, Chair

Megan Hopper

Philip Chidester 


\section{ACKNOWLEDGMENTS}

First, I would like to thank God for His providence toward the completion of this project. In the words of the Psalmist (136:1), I give thanks to the Lord, for He is good.

My heartfelt gratitude goes to my advisor, mentor, and committee chair, Dr. John Baldwin. Thank you for your guidance, expert advice, and support. This project would not have been complete without your contribution, sir. I enjoyed your wit, humor, and personality, I will miss this! Asante sana, Daktari!

I am also grateful to the faculty who accepted to serve in my committee, Dr. Megan Hopper and Dr. Philip Chidester. Your feedback was incredibly helpful. Thank you!

I wonder how I would have completed this project without the moral and academic support from friends. Misha Khan, thank you for always cheering me on and for always reminding me that life is more than just work, to leave my apartment, and have fun occasionally. Ashley Morrison-Sain and Divine Aboagye, your positive energy amazes me, thank you great people!

Lastly, I will always be indebted to the School of Communication for giving me an opportunity to earn my graduate degree while working with excellent faculty and staff. This also extends to Dr. Cheri Simonds, by supervisor, for your belief in my teaching, your advice, and the opportunities you accorded me.

G.K. 


\section{CONTENTS}

Page

ACKNOWLEDGMENTS

$\begin{array}{ll}\text { CONTENTS } & \text { ii }\end{array}$

TABLES Di - vi

CHAPTER I: INTRODUCTION 1

Past Research on Media Use and Political Attitudes and Behaviors 3

$\begin{array}{ll}\text { The Current Study } & 4\end{array}$

$\begin{array}{lr}\text { Conclusion } & 6\end{array}$

$\begin{array}{ll}\text { CHAPTER II: LITERATURE REVIEW } & 7\end{array}$

$\begin{array}{ll}\text { Conceptualizing Political Culture } & 7\end{array}$

$\begin{array}{ll}\text { Defining Political Culture } & 7\end{array}$

$\begin{array}{ll}\text { Types of Political Culture } & 8\end{array}$

Participant culture 9

$\begin{array}{ll}\text { Subject culture } & 9\end{array}$

$\begin{array}{lr}\text { Parochial culture } & 9\end{array}$

Political Cultures Across the Globe $\quad 9$

$\begin{array}{ll}\text { American Political Culture } & 10\end{array}$

$\begin{array}{ll}\text { Beliefs } & 10\end{array}$

$\begin{array}{ll}\text { Egalitarianism } & 11\end{array}$

Individualism 11

$\begin{array}{ll}\text { American values } & 12\end{array}$

$\begin{array}{ll}\text { Political participation and civic engagement } & 13\end{array}$ 
$\begin{array}{ll}\text { Political Culture in Latin America } & 14\end{array}$

Democracy in Latin America 14

$\begin{array}{ll}\text { Political militarism } & 15\end{array}$

$\begin{array}{ll}\text { Corruption and political distrust } & 15\end{array}$

$\begin{array}{ll}\text { Political participation } & 16\end{array}$

$\begin{array}{ll}\text { Political Culture in Asia } & 16\end{array}$

$\begin{array}{ll}\text { Political trust } & 16\end{array}$

$\begin{array}{ll}\text { Political participation } & 17\end{array}$

$\begin{array}{ll}\text { Popular support } & 17\end{array}$

$\begin{array}{ll}\text { Patriotism and national pride } & 18\end{array}$

$\begin{array}{ll}\text { Media space } & 18\end{array}$

$\begin{array}{ll}\text { African Political Culture } & 19\end{array}$

Democracy and Political Participation in Africa 20

$\begin{array}{ll}\text { Ethnicity and Elections } & 21\end{array}$

$\begin{array}{ll}\text { Kenya's Political Culture } & 23\end{array}$

$\begin{array}{ll}\text { Kenya's Exceptionalism } & 23\end{array}$

$\begin{array}{ll}\text { Political Trust } & 24\end{array}$

$\begin{array}{ll}\text { Ethnicity in Kenyan Politics } & 24\end{array}$

$\begin{array}{ll}\text { Historical perspective } & 26\end{array}$

Media in Kenya and its Evolving Relationship with Politics 28

Media Effects on and Relationship with Politics 29

$\begin{array}{ll}\text { Civic and Political Engagement } & 29\end{array}$

$\begin{array}{ll}\text { Public Trust in Government } & 31\end{array}$ 
Patriotism

Negative Ethnicity

Summary

Research Questions

Conclusion

CHAPTER III: METHOD

Participants

Sampling Procedure

Measures

Media Consumption

TV news consumption

Newspaper consumption

Radio news consumption

Online news consumption

Political Interest and Participation

Political Trust

Patriotism

Ethnic Attitudes

Data Analysis

Conclusion 
CHAPTER IV: RESULTS

Scale Reliabilities $\quad 44$

Pearson Product-Moment Correlations 44

$\begin{array}{ll}\text { Conclusion } & 47\end{array}$

$\begin{array}{ll}\text { CHAPTER V: DISCUSSION } & 48\end{array}$

$\begin{array}{ll}\text { Summary of Findings } & 48\end{array}$

Research Question One $\quad 48$

Research Question Two $\quad 52$

Research Question Three $\quad 53$

Research Question Four $\quad 54$

Implications $\quad 56$

Theoretical Implications $\quad 56$

$\begin{array}{ll}\text { Methodological Implications } & 60\end{array}$

$\begin{array}{ll}\text { Practical Implications } & 63\end{array}$

$\begin{array}{ll}\text { Conclusion } & 64\end{array}$

REFERENCES

$\begin{array}{ll}\text { APPENDIX A: EMAIL INVITATION } & 77\end{array}$

$\begin{array}{ll}\text { APPENDIX B: INFORMED CONSENT } & 78\end{array}$

APPENDIX C: SURVEY INSTRUMENT $\quad 80$ 


\section{TABLES}

Table

Page

1. Pearson Product-Moment Correlations for Media Consumption and Patriotism,

Political Trust, Political Participation and Inter-Ethnic Attitudes 


\section{CHAPTER I: INTRODUCTION}

"Man is by nature a political animal," is perhaps Aristotle's best-known saying. It is not just a cliché in the English language, given the frequency with which it is quoted, but, instead, its usage suggests that its meaning is thought to be transparently clear. It portrays how the importance of values, beliefs, and social norms in a political system have preoccupied political philosophers throughout history. Political scientists, students of contemporary politics, rhetoricians, psychologists, communicators, and even anthropologists have, since the ancient days of Plato, immersed themselves in the scholarly inquiry of politics and its impact on human life. This study will add to that body of knowledge in this field.

Aristotle's statement demonstrates the fact that humans cannot unyoke themselves entirely from politics. It is probably true that, for most people, politics is a peripheral aspect of their life. Certain technical aspects of politics may not command the attention of the public. In fact, no zealous proponent of good citizenship would and should argue that political engagement and interest ought to be pursued at the expense of all other obligations. However, despite a lack of political interest, members of the public subscribe to shared opinions, views, beliefs, and values on how political leaders should run the affairs that affect them as well as how they should conduct themselves. This is what I would refer to as a people's collective political-cultural orientations or simply, political culture. But to get a deeper appreciation of these politico-cultural orientations, there is need to examine its source, culture.

Culture is a notoriously difficult term to define. This is mainly due to the multitudinous definitions that have been proctored by cultural scholars and anthropologists (Baldwin, Faulkner, $\&$ Hecht, 2006). Over 50 years ago, American anthropologists, Kroeber and Kluckhohn (1952), analyzed the existing definitions and compiled a list of 150 different definitions. A writer 
laments about these definitions of the term, arguing that the term "has so many definitions and facets that any overlap in this myriad of definitions might actually be absent" (Yengoyan, 1989, p. 3). This slippery and ubiquitous nature perhaps led Baldwin et al. (2006) to note, "The definition of culture is a moving target, and those who choose to define it should ground their definitions in a fuller, multidisciplinary, and historicized accounting of the word" (p. 24). The following definitions give meaning to this "empty shell". According to Barnett (1988):

Culture consists of the habits and tendencies to act in certain ways, but not the action themselves. It is the language patterns, values, attitudes, beliefs, customs, and thought patterns - not things or behaviors, but forms of things that people have in mind, in their models for perceiving, relating, and otherwise interpreting them. (p. 102)

However, in this study, culture is operationalized following Kroeber and Kluckhohn's (1952) summarized definition-which is broader as it goes beyond the patterns of thought advanced by Barnett to include action and behavior:

Culture consists of patterns, explicit and implicit, of and for behavior acquired and transmitted by symbols, constituting the distinctive achievements of human groups, including their embodiment in artifacts; the essential core of culture consists of traditional (i.e., historically derived and selected) ideas and especially their attached values; culture systems may, on the one hand, be considered as products of action, on the other, as conditional elements of future action. (p. 181)

Clearly, the definitions above converge on the idea that culture consists of something that is shared and/or learned by a group of people even though the content of its definitions vary. These shared convictions, values, beliefs, and skills have a significant impact on politics, especially on democratic institutions (Inglehart, 1988). Putnam (2000) also argues that politics 
(e.g., political participation) cannot be examined in isolation of the culture of the masses.

Moreover, Putnam posits that the success or failure of democratic institutions reflects the degree to which a culture of trust and participation is present, the two key variables in this study.

Culture influences the relationship between polity and society, hence the term political culture.

Political culture, according to Inglehart (1988), varies from one society to another and is passed on from one generation to the next through a process called socialization. One of the prominent socializing agents is the mass media which are rich sources of information about the politics, current affairs, and the government. But the seminal question here is: Does the media consumption have any relationship with people's political attitudes and behaviors (political culture)?

\section{Past Research on Media Use and Political Attitudes and Behaviors}

A substantial body of research has documented the relationship and the effect of the mass media on the formation, change, and/or stabilization of political opinions and attitudes. For instance, McCombs and Shaw's (1972) agenda-setting inspired literature that has provided evidence that the mass media influence the judgment of important issues by the public following its prominence in the media Shah, Shmeirbach, Hawkins, Espino, and Donovan (2002) suggest that increased online media use have a negative relationship with political interest and participation, while Kenski and Stroud (2006) offer opposing view by arguing that the use of the Internet for informational purposes have a positive relationship with political efficacy, knowledge, interest, and participation Voter turnout studies in the United States suggest that increased exposure to television significantly reduces political participation (Putnam, 2000) while exposure to hard news in the print media is associated with higher turnout and other forms of participation as well (McCleod \& McDonald, 1985). These landmark studies have 
demonstrated empirically how the news comes to shape public understanding of politics and its relationship with citizen's political knowledge, and by extension, political interest, patriotism, trust, participation, and racial and/or ethnic attitudes. However, many of these studies have been conducted in the United States and other "western"” countries.

Despite the prevalence of research on the relationship between and the impact of the news media on political attitudes and behaviors, little attention has been given to such influences in the continent of Africa. Given this scholarly 'blackout' and the significance of the news media on African politics, more empirical investigations are thus warranted in this area.

\section{The Current Study}

Ever since Almond and Verba (1963) conducted and published their five-nation study, The Civic Culture, scholars have sought to extend and/or replicate the study in other jurisdictions and countries. Despite the tremendous success in these replica studies, very little has been documented about Africa and, more specifically, Kenya. Anglo-American studies continue to dominate the scholarship on politics, political culture, and political communication. (Sanders, 2009). Asian research is also becoming well-established while studies about Africa, its culture, its people, its politics, and other facets remain understudied. Thus, Nwosu (2005) argues that there is a need to study and understand how Africans draw from their cultural patterns in conducting their affairs, in this case, in their political affairs.

Africa is the home to over one billion people, over 1500 different languages, and about 3000 ethnic groups spread over 54 countries (Nwosu, 2005). While this vast continent provides "a treasure trove of opportunity for scholarly inquiry...not much has been done" (Nwosu, 2005, p. 2). This study is an attempt to fill this void by providing a better understanding of one of the 
African countries, Kenya. Specifically, the relationship between media use and political attitudes and behaviors in Kenya will be examined.

Kenya is an East-African country with a population of approximately 45 million people, and 43 native ethnic groups as well as Europeans, Asians, and Arabs. It is the region's economic hub (Kenya National Bureau of Statistics, 2016). Historically, the remains of human fossils were found here leading many to believe that it is the birthplace of humankind. The country named after Mount Kenya, which is a significant landmark and the second highest mountain peak in Africa, has been described as a lively cultural storehouse with gracious people (Kanyinga, 2014). People greet visitors with 'jambo?' (greetings!) or 'habari gani?' (what's the news?). Kenyan athletes have thrilled the world in long-distance races by winning world major marathons and track events. It is a country well known for its exotic Maasai community with conservative cultures and, particularly, its unique traditional regalia. Kenya is a kaleidoscope of culture and land; when it is mentioned, people think about its wildlife. However, the pride of most Kenyans lies in their culture, their families, sports (athletics), and in their land (country), and, only after that, in their wildlife. Beyond this rich and complex description is the people's orientations toward politics. The Swahili word 'harambee' (meaning pull together) fittingly describes this diverse and unique country, especially its style of politics characterized by deep ethnic cleavages. This is an aspect of the Kenyan way of life that will be explored in this study. Kenya's political culture is well documented in literature (Mukhongo, 2009: Shilaho, 2018). However, the relationship between the prevailing political attitudes and behaviors (political culture) and self-reported media use habits in Kenya remains understudied. As such, the purpose of this study is to investigate, explain, and thus, address a major limitation in understanding Kenya's political culture, namely the relationship and the perceived influence of 
the Kenyan media on Kenya's political culture. This study examines the relationship between media consumption and the various variables that form a nation's political culture within the framework of media effects theories.

Previous conceptualizations of political culture include several aspects (Almond \& Verba, 1963), but in this study concentrates on four major dimensions of society's political culture; (i) political interest and participation, (ii) political trust, (iii) patriotism, and (iv) interethnic attitudes in Kenya.

The remainder of this paper is organized as follows: Chapter two conceptualizes political culture and explores extensively political cultures across the world with a review of literature. The chapter also addresses the prevalent political cultures in Africa as it narrows down to the political culture in Kenya. Additionally, there is also a discussion on the political communication effects regarding political interest, patriotism, participation, trust, and ethnicity. Finally, integrated in the chapter are research questions guiding this study. Chapter three outlines the methods to be used in the study and how each variable will be measured. Chapter four will present the findings after the analysis of the collected data and chapter five will present a thorough discussion and summary as it also identifies the limitations of the research as well suggestions for further research.

\section{Conclusion}

This chapter has provided an overview of the political culture, the influence of the mass media on politics, and the context-Kenya-where the study will be based. The next chapter will provide a deeper understanding of political cultures across the world, in Africa, and finally, in Kenya. The impact of the news media on political attitudes will also be documented, thus setting a bedrock for the research questions that will guide this study. 


\section{CHAPTER II: LITERATURE REVIEW}

A useful scholarly inquiry on political culture and its perceived relationship with the media, requires an examination of previous research. This chapter provides a summary of the extensive gains made in scholarly knowledge in conceptualizing political culture and the media's role in entrenching, changing, reflecting, or influencing an individual's and or society's political culture. First, the chapter suggests a conceptual understanding of political culture. Second, this section will review studies on political cultures across the world, in Africa, and lastly, in Kenya. Then, it will provide a coverage of media effects/relationships with political attitudes, values, beliefs as well as behavioral implications. In this way, previous studies will provide a basis upon which the researcher will pose research questions to guide the study.

\section{Conceptualizing Political Culture}

\section{Defining Political Culture}

An examination of previous literature suggests that descriptions of political culture range from the highly elaborate and declamatory definition by Almond and Verba (1963) that political culture refers to "the political orientations - the attitudes toward the political system and its various parts, and attitudes toward the role of the self in the system" (p. 13) to the description by Wilson (1997) that simply defines political culture as a country's political personality. However, Wilson further expounds that a political culture consists of well-established, deep-rooted political traits that are a feature of a society. This definition by Wilson demonstrates the relationship between political culture and the plain old culture, since political culture stems from the overarching convictions shared by a people, albeit, regarding politics.

Elazar (1994) comments that political culture is also made up of what is sometimes referred to as "habits of the heart," which includes formal rules as well as customs and traditions 
that are passed on from one generation to the next. For example, people agree to abide by a set of formal regulations, such as the constitution and other statutory laws. People also live by the unwritten rules such as the norm in the United States to accept election results without necessarily resorting to violence. It is what Elazar (1994) terms as political culture that sets the boundaries of acceptable political behavior in a society. Additionally, the shared political customs and traditions are what help people to create and share an understanding of why and how certain political processes and activities occur in their country, thus building their communities through shared communication. De Silva, Clark, \&, Vieira (2015) defines political culture as a system of political symbols, and this system nests within a more inclusive system that we might term political communication.

Swedlow (2011) offers a unique perspective toward understanding political culture. The scholar argues that if politics poses the question of "who gets what, when, where, and how," then, Swedlow says, political culture supplies a big part of the answer. "If politics is the art of the possible, then political culture helps define the limits of that art, for culture defines what is generally permissible in a given society” (p. 2). According to Swedlow, political culture (defined as the shared values and beliefs of a group regarding political relationships and public policy) answers the question of how human beings are going to live together. In addition, Swedlow posits that political culture answers the question of who decides, who has authority, and who has power in a group, organization, institution, or other social unit in society.

\section{Types of Political Culture}

Citizens hold different attitudes toward political objects and processes, which consequently puts them in different categories of political 'subcultures' (Almond \& Verba, 1963). These classifications, according to Almond and Verba, include; 
Participant culture. In this first category, individuals have positive orientations toward a political system and are, therefore, active players within the system. Additionally, the citizens pay close attention to politics and regard popular participation as desirable and useful.

Subject culture. This second category is characterized by passivity of citizens and recognition of limited ability to influence the government. It includes individuals who have positive orientations toward the political system but play passive roles in the system.

Parochial culture. This third category includes individuals who are indifferent toward the political system and tend to be politically passive. A parochial political culture is marked by the presence of a sense of citizenship, with people identifying more with their locality than their nation (Wilson, 1997). According to Almond and Verba (1963), these political subcultures blend to create the political culture of a society.

Given the paucity of studies that explore Kenyan political culture as well as its relationship with media use by the Kenyan people, a gap that I hope to help fill with this study, an exploration of political cultures across the globe is thus warranted. In doing so, I hope to highlight the unique political orientations that are characteristic of different countries worldwide and that are significant in understanding the shared political attitudes and behaviors (operationalized as political culture) of the Kenyan people.

\section{Political Cultures Across the Globe}

In political-cultural studies, scholars focus on the political attitudes, values, beliefs, and ideologies that are associated with and that explain the political behaviors of individuals or groups of individuals of a nation. Almond and Verba (1963) are credited with conducting a ground-breaking study on political cultures across five democracies namely, the United States, Britain, Germany, Italy, and Mexico. They selected the United States and Britain because the 
two countries represent relatively successful experiments in democratic political systems. The choice of Germany was due its historical blend of fascism and, later, democracy. Italy and Mexico were also included because, during the time of the study, they were "examples of less well-developed societies with transitional political systems" (Almond \& Verba, 1963, p. 39). As will be demonstrated below, this study provided the necessary spark that led political scientists and other students of contemporary politics into further research beyond Almond and Verba's initial five "mother" countries.

\section{American Political Culture}

A colossal body of research studies is available on the distinct and conventional style of politics in America, at least until recently, when the country witnessed populist political styles espoused by the front runner and the eventual winner of the presidential elections, Donald Trump. This wave of populism described by Garrido (2017) as a manner of acting and speaking that serves to cultivate the popular identification, consists of "tactics such as anti-elite rhetoric and the flouting of social conventions" (Garrido, 2017, p. 2). President Donald Trump played this ace card successfully to secure the presidency. That notwithstanding, numerous scholars have examined the effects of the media on the American public, particularly, on the public's political attitudes which subsequently determines their political behaviors. But first, a closer look at the elements of the American political culture, that Wilson (1997) posit are both abstract and concrete.

Beliefs. America is built on the principles of equality and liberty (McClosky \& Zaller, 1987). There is a widely held believe in America that individuals should be free to do as they will, that they have the right to be free from restraint as long as one's rights do not infringe on those of the other people. The founding fathers of American democracy, during their Declaration 
of Independence, endorsed the principles of equality and liberty, rights and freedoms that are now enshrined in the constitution (Bennett, 1980). However, McClosky and Zaller (1987) argue that the concept of equality should be understood in terms of "equality of opportunity" not absolute equality. These two key principles that have been incorporated into the political culture of the United States in the form of egalitarianism and individualism.

Egalitarianism. Is the doctrine of equality of humans and its emphasis of the absence of superiority of a set of humans over others (Hunter \& Bowman, 1996). This central American belief is found in the preamble to the Declaration of Independence, which states that all men are created equal and that people are endowed with the unalienable rights to life, liberty, and the pursuit of happiness (Bennet, 1980). This is demonstrated by the act of Americans treating each other as equals, whatever their education, occupation or social class. However, scholars are quick to point out that that this form of equality implied equality of opportunity rather than equality of condition or economic equality (Schlozman, Verba \& Brady, 1999). They also assert that even though the concept of equality is hardly achieved due to discrimination based on race and sex, the belief is still highly entrenched.

Individualism. Gudynkust and Ting-Toomey (1988) posit that, "Basically, individualism refers to the broad value tendencies of a culture to emphasize the importance of individual identity over group identity, individual rights over group rights, and individual needs over group needs" (p. 376). There is a devotion in America to individualism (Hunter \& Bowman, 1996). The scholars argue that it is highly valued and has permeated almost every facet of life including politics, religion, and education. Consistent with the constitution's preoccupation with liberty, individualism is also what drives American parents to teach their children that individuals can succeed through hard work, perseverance, and self-reliance. These core American beliefs 
permeates every aspect of the public's lives and are consequently reflected in the political spheres of the American public and predictably, shape the nation's political climate and practices.

American values. Wilson (1997) notes that beliefs provide the foundation for values which refers to a society's shared convictions of what is just and good. According to Hunter and Bowman (1996), the core American values are vested in in the American creed. These values include but are not limited to the following: (i) Democracy: If democracy is defined in terms of a simple devotion to ruling with consent of the governed, then there is no doubt that Americans cherish it. The American creed states that the United States government is a government by the people, for the people, whose just powers are derived from the governed (Schlozman, Verba \& Brady, 1999). Americans value a majority rule, a representative government, and the rights of an individual (Hunter \& Bowman, 1996; Wilson, 1997). Most Americans believe that democracy is the best of government and will therefore, lend support to initiatives aimed at expanding and protecting democracy (Pew Research Center, 2009). (ii) American exceptionalism: Americans strongly believe that the United States is the best and the strongest nation on earth (Sullivan, Piereson, \& Marcus, 1982). It is the view that America has earned its place in the world through exceptional development and that its vast frontiers offers boundless and equal opportunities for all to succeed with sheer hard work and perseverance. According to Hunter and Bowman (1996), Americans feel that the United States serves as an example to other countries. (iii) Nationalism and patriotism: When Almond and Verba (1963) investigated the political culture in the United States almost 50 years ago, they discovered that Americans "have a high degree of pride in their political system" (p. 440). American's love for their country is summed up by the maxim that says that virtuous citizens display a sense of devotion to their country and the fundamental 
values that it upholds. The Pew Research Center (2009) posits that despite the negative attitudes toward the government and the distrust held toward the political elite, most Americans are proud of their country and their past and, yet do not emphasize their past but focus on their future. This is seen in the way Americans support their military, embrace the American flag, and sing the country's national anthem.

These cultural artefacts and symbols (such as the spirit of individualism, egalitarianism, and exceptionalism) have transcended the plain old cultural scope to reflect the nation's political climate. Basically, these are core values that predictably shape America's political climate and practices.

Political participation and civic engagement. Almond and Verba (1963) described the American public over 50 years ago as being frequently exposed to politics, engaging in political discussion, being involved in political affairs, having a sense of obligation to take active part in the community, and having a sense of competence to influence the government. However, as Putnam (2000) found five decades later, there was a decline in American participation in political activities ranging from signing petitions, attending rallies to voter turn-out. Putnam presented a stereotypical view of a new generation young Americans as 'couch potatoes.' Putnam laments that America is reminded each year that fewer voters show up at the polls than in most other democracies. Attempts to explain this decline have largely centered on young people, though participations have been dropping for all age groups, Putnam posits that youth political engagement has been the most precipitous because it is the most affected segment of the population. Although mitigated somewhat by the modest upward movement of voter turnout during the 2004 and 2008 elections (Cebula, Payne, \& Saltz, 2017), concern regarding low (and declining) voter turnout in the U.S. nevertheless is expressed frequently in the media and 
elsewhere. In a cross-cultural analysis between the Turkey and the United States on

argumentativeness and political participation, Croucher et.al (2013) found that in 2008, the voter turnout in the United States was $56.9 \%$ while Turkey had a voter turnout of $84 \%$.

To get a general outlook of the variations and or similarities in political cultures across the globe, there is also need to document literature on the political attitudes and behaviors of other countries, with uniquely different political systems from that of the United States.

\section{Political Culture in Latin America}

Democracy in Latin America. "The region has many problems," noted The Economist in a 2002 cover story, "but democracy, as such, is not one of them." This is a comment that may raise eye brows of many North Americans because of the entrenched perception that democracy cannot thrive in South America. However, political scientists and communicators echo that indeed, democracy has weathered the storms of militarism and warlordism to be where it is now. The Economist published that warlordism, juntas, and coups are no longer a problem since most Latin American countries have embraced democratic ideals. In fact, Salinas and Booth (2009; 2011) found that in 18 Latin American countries, most people have a strong liking and support for democratic ideals. There is generally a high consensus and drive toward strengthening a participatory democratic political culture with an entrenched dislike for authoritarianism and military coups (Booth and Richard, 2011). Encarnación (2003) poses the question, "What accounts for the growth and flourishing of democratic ideals in Latin America?” (p. 4) The answer derives seemingly, in large part, from what Koonings and Kruijt (2003) describe as a

profound transformation of political attitudes and thus, political culture. Latin Americans value democratic governance for the political freedoms and civil rights that accompany it above the social and economic benefits it may or may not deliver (Arce, 2003). 
Political militarism. The political culture in Latin America has not always been characterized by a representative government, a majority rule, and an active citizenry. Koonings and Kruijt (2003) argue that Latin American countries (such as Chile and Venezuela) have not always been models of democratic practice. The region, since independence, was the land of revolutions, military seizures of power, and brutal dictatorships. In fact, Arce (2003), extends this point further and states that "twentieth century Latin America has been the continent of political soldiers and military politicians" (p. 1). The military have intervened several times to act as a stabilizing force during political chaos, as a disinterested arbiter, to protect the power of the constitution, and as guardians of national development. In this intervening activity, generals became politicians in military uniforms.

Corruption and political distrust. Corruption is major problem in some parts of the Americas. According to a report compiled by the World Bank, corruption trails crime and the economy in terms of the issues about which South Americans are most concerned. While the levels of corruption vary from one country to another, bribery in several Latin American countries is an everyday occurrence (Ugur, 2014). Studies show that corruption has enormous negative effects such as slowing down economic growth), skewing wealth distribution, and lowering the efficiency and effectiveness of public services (since resources meant for public programs are diverted for personal gain (Ugur, 2014). Corruption has pernicious political, economic, and social effects. Additionally, corruption discourages citizens from political engagement. When citizens witness rampant corruption by public officials while no action is being taken against them, apathy tends to creep in. 
Political participation. A 2014 study conducted in the Americas by the US state department found that citizens of Chile, Panama, and Argentina participate passively in municipal meetings, political rallies, and other forms of local-level participation. In the report by Zechmeister (2014), citizens attribute their passive participation to government inefficiency, massive corruption, and stagnant economies. Despite the challenges faced in the Latin American countries, the levels of trust in the government is uncharacteristically high. For example, Zechmeister reports that trust in the government is very high in Nicaragua and Chile.

\section{Political Culture in Asia}

A study of cross-national political cultures in Asia might begin with a study of the political cultures of two neighboring countries that seem to closely mirror each other, China and Singapore. China has been described as a downstream manufacturing powerhouse and a revolutionary force in the global space (Chang, 2015). Singapore, once described as a colonial backwater (Rae, 2001) and the Disneyland with the death penalty (Kluver, 2004), has a fascinating story of enormous economic development into one of the richest and most developed Asian nations after just handful years of independence.

Political trust. According to $\mathrm{Li}$ (2004), people in mainland China generally have more trust in the central government and less trust in local government. Li argues that this is because of strict media surveillance against negative information about the central government as compared to the local government. The situation in Hong Kong is different because the media still play the watchdog role of holding the government in check, thus eroding the public trust in government through negative reports. Li also notes that distrust is particularly prominent among Hong Kong youth who have unrestricted access to Internet and social media, where they can get information and thus criticize the government, which may lead to reduced political participation. 
Political participation. Political participation in Mainland China is different from that of well-established democracies (Chan, 1994). Citizens have limited channels to participate in politics. Li (2004) posits that central officials are not elected through open, free, fair general elections. Even when elections are held at the local level, the avenues for political participation are limited because the nomination and subsequent elections of elections are manipulated by the Chinese Communist Party (CCP). In addition, traditional political participation through voting, petitioning, and demonstration form a part of the participation by the Chinese. Similarly, in Singapore, the elections in this country, referred to by economists as an "Asian tiger," is characterized by heavy manipulation (Mutalib, 2000). In addition, the electorate are described by Chia (2016) as passive and parochial, more concerned with bread-and-butter issues than with human rights, social justice, and the notion of democracy. According to Chia, this conservative nature of Singaporeans has enabled the ruling party, the People's Action Party (PAP), to hold on to power since Singapore split from Malaysia in August 1965. Despite winning economic accolades for its economic policies, its political culture has been described as immature (Chia, 2016).

Popular support. Despite its autocratic nature, and perhaps surprisingly, the authoritarian regime in China enjoys one of the highest levels of popular support in Asia, higher than that enjoyed by many democratic regimes in the region (Domestic politics, 2010). At the same time, there are fears that Singapore is slipping away from a 'guided democracy' to a 'soft authoritarianism' (Welsh, 2015). This notwithstanding, the government enjoys unprecedented public support. Indeed, according to a 2010 survey by US-based PR firm Edelman, trust in Singapore's government stood at $84 \%$, far ahead of the global average of $49 \%$, thus ranking the country first out of the 22 surveyed (Domestic politics, 2010). 
Patriotism and national pride. Right after independence, the government of Singapore revamped its education syllabus in the hope of inculcating the values of patriotism, loyalty, and civic consciousness in the context of a multiracial society (Chew, 1988). The appreciation of this early nature of citizenship education is important in understanding the contemporary political culture in Singapore (Chia, 2016). The civics syllabus for example was designed to "reflect the concerns of the authorities toward developing a sense of national identity in children" (Sim \& Print 2009, p. 706). The emphasis was placed on character development, good habits, moral development, and citizenship responsibilities with an objective of stimulating patriotic feelings and making children staunch citizens (Ong, 1979). In short, Singapore, through the school syllabus, to foster in Singaporean pupils a sense of civic and social responsibility as well as "a love for its country and its people" (Ong, 1979, p. 3). According to Chia (2016), the 2015 election result in Singapore in which the ruling party PAP maintained its dominance should not be surprising, the election affirmed the success of the citizenship education relentlessly taught in schools.

Media space. The People's Republic of China has arguably one of the most restrictive media systems in the world (Chan, 1994). The government notoriously controls all media outlets to maintain its monopoly on power and information. Chan also asserts that knowledge is the main catalyst of political change, and, for fear of this, the Chinese government has been successful in stifling independent reporting and critical journalism, which can lead to political mobilization and ultimately political change. The Singaporean government on the other hand has also developed a firm control over online media and narrowed the scope of political debate in mainstream media (Domestic politics, 2010). 
Political cultures vary across the globe, as demonstrated above. The United States, with rich literature on political culture, exemplifies a democratic political system based in the country's belief in the rule of law, political tolerance, liberty, high national pride, high political cynicism, and decreasing political participation. Latin America is characterized by maturing democracies to the "surprise" of many. The South American countries have shaken off the tag of dictatorships as a result of changing political attitudes that have led to a transformation of political cultures. The Asian countries reviewed, China and Singapore, portray authoritarian political systems characterized by a one-party system and centralized power. Moreover, the two economic giants stifle media freedom, restrict academic discourse on human rights and democracy, and do not tolerate critics. Despite the prevailing political atmosphere, which may seem bleak and retrogressive, the two regimes enjoy massive popular support for their economic policies. Since this study focuses on a country specific political culture, a summary of the political culture of the African continent is important.

As demonstrated above, Asian political cultures can be somewhat similar regionally but with unique national differences. Similarly, the Americas have certain closely related political characteristics but different orientations by country. The same trend is thus expected in the vast African continent. Since this study focuses on a country specific political culture, a more focused summary of the African continent is important as it narrows down to the specific context of the study, Kenya.

\section{African Political Culture}

This study investigates the relationships between media consumption and political culture (i.e., political-orientations, attitudes, and traditions) of the Kenyan people. Therefore, to better understand the political culture of this unique African community and its possible relationship 
with the media, it is important to explore the nature of politics in the entire African continent as established in previous studies.

According to Carlson (2015), traditional African culture consists of sub-Saharan African values, beliefs, cultural themes, and behaviors that existed before the arrival of the Europeans. These enduring beliefs and values inform the behaviors of the African people to date. Some of these values and core cultural themes include the emphasis on the community rather than the individual (collectivism, the belief in the proverb that says, "I am because we are" or Ubuntu); hospitality and friendly disposition of Africans (friendship is not perceived as a temporary affair, friends become part of family to the extent that long-time friends are considered cousins); strong religious attachments; time is conceptualized in terms of connections and not schedules (the strong belief that one must not be a slave to schedules);, a natural tendency to be patient, tolerant, sympathetic, and accepting.

However, Moemeka (1996) cautions against the idea of a single "umbrella" culture in the entire African continent. She posits that despite the existence of common and uniquely African cultural threads, there exists certain unique differences and thus, unique African cultures. Moemeka asserts that African beliefs can be obtained anywhere across Africa and have a huge impact on the communicative behavior of Africans everywhere. I would also argue that these African orientations permeate the political lives of the African people.

\section{Democracy and Political Participation in Africa}

Africa's political landscape has changed dramatically in the recent past. Following the collapse of old regimes that took over from the colonialists, African countries embarked on transitions to multi-partism that were initially welcomed as the beginning of a continent-wide wave of democratization (Call, 2008). This led to the rise of vibrant civil societies, multiparty 
politics, and free press. Just as in Latin America, the simplistic generalization that democracy is foreign to Africa is misguided. Several African countries have stable democracies: Such as, Kenya, Ghana, South Africa, and Botswana (Kanyinga, 2009) However, in certain countries such as Congo, democracy is merely a concept (McLaughlin, 2007) With the rise of regular elections, political elites devised strategies to hold on to power and thus pitted one ethnic group against the other. In fact, McLaughlin found that there is a very strong correlation between ethnicity and voting choice in several African countries. This speaks to the style of political participation of in some countries in the continent.

\section{Ethnicity and Elections}

Call (2008) notes that perhaps the most studied phenomenon in all of African political behavior is the tendency of voters in many parts of the continent to support political candidates of their own ethnicities. According to Call, voters exercise these democratic rights in support of co-ethnic politicians even in the absence of prejudice but in the hope that these politicians will steer resources to their own ethnic group at the expense of other groups. Research has found that ethnicity strongly predicts vote choice in Kenya and Ghana (Bratton \& Kimenyi, 2008) even though voters may still report that ethnicity is not a factor in their vote choice, and, while some consider ethnicity in the privacy of voting booth, they downplay its importance when they report their decision-making to others (Basedau \& Stroh, 2009). This is somewhat similar to Barack Obama's 2008 elections and the factor of race. Up until 2008, it would have been almost impossible to gauge the tendency of Americans to vote for someone from their own ethnicity, since until 208 there had never been a non-white candidate for president from either of the two key political parties (Bobo \& Dawson, 2009). Did Barack Obama's success transform America's racial divide? Did he somehow help bring to an end centuries of racial division in the United 
States? The answer to this is largely in part seen from the support Obama received from white Americans and most significantly from black America. "Race was a major undercurrent in the campaign" (Bobo \& Dawson, 2009, p. 2). However, "small but continued minorities of white admitted that race was a factor in their support for Hillary Clinton, as one in ten said in South Dakota ... Obama was never able to make sustainable inroads with the white working class, female, and white older women" (Bobo \& Dawson, 2009, p.3). It is plausible to argue that support toward co-ethnic member is a human tendency rather than solely African.

Crook (1997) found that, when given no other information about a pair of hypothetical candidates, $80 \%$ of Ugandans and $87 \%$ of Kenyans select the candidate who shares their ethnicity. Despite ethnicity often playing a role, its impact differs from country to country, and is just one of a number of factors impacting political culture. For instance, ethnicity is not salient at all in some countries such as Tanzania (Basedau \& Stroh, 2009). Ethnic voting may be construed as a manifestation of 'tribalism,' which is censured in some African societies, where it is portrayed as socially unacceptable despite its rampant nature, just as racism is in the United States (McLaughlin, 2007).

As previously argued by Moemeka (1996), every African country is unique even though there are certain behaviors and/or orientations that are uniquely African and will be obtained everywhere in Africa. This study investigates country-specific political orientations. Therefore, a summary of Kenya's political culture is also important. 


\section{Kenya's Political Culture}

Kenya, the economic and political economic hub of East Africa (Miller \& Yeager, 1994), is a country defined by the diversity of its people and cultures. It is a country whose political story is a grand narrative woven in high drama and intrigue. To precisely describe Kenya's political system is a tremendous challenge. Some scholars, like Mukhongo (2009) describe Kenya as capitalist in nature but with a touch of African socialism.

\section{Kenya's Exceptionalism}

Kenya may not be influential on a global scale, but its place as a beacon of democracy and political stability shines bright. Lonsdale (1992) notes that Kenya's unique story lies in its economic growth, despite the lack of minerals, and its political openness and stability, a situation similar to that of many other African and European countries. Mukhongo (2009) also comments that Kenya's history has not been one of war, military rule, mass murder, or state collapse. Even though the country's narrative may not be characterized by its influence on the world economy, Kenya is one of the most stable democracies in Africa with its people beaming with national pride (Oyugi, Wanyande, \& Odhiambo-Mbai, 2008). Similarly, Kanyinga (2014) posits that, unlike most African states, Kenya has avoided military rule, social instability, warlordism, mass murder or social collapse. Additionally, religious divisions have not led to violence as in Nigeria. Moreover, Kenya is one of the few countries in Africa that conducts elections regularly (Mukhongo, 2009), and the losers in the general elections do not resort to war when they lose even though there are occasional ethnic clashes as a result of disputed elections (Lonsdale, 2004). Kenya is also a force to reckon with, politically and economically, in East and Central Africa (Amutabi, 2013). 


\section{Political Trust}

According to the World Values Survey (2010), which asks citizens around the world about their activities, beliefs, and opinions, Kenyans have been found to be less trusting compared to their neighbors Tanzanians. Indeed, compared to other African societies, Kenyans trust strangers more than their countrymen. Similarly, local polls conducted in Kenya by Ipsos Synnovate have consistently found that Kenyans lack trust in key democratic institutions. A survey conducted in 2017 by Twaweza East Africa, a Kenyan firm, shows that Kenyan politicians are the least trusted in the society while the media, religious leaders, and civil society remain the most trusted.

From the fountain of constitutional amendments that led to the advent of political pluralism in Kenya and consigned political dictatorship to the dustbin of history, ethnicity reared its ugly head. In fact, Shilaho (2018) notes that politicians exploited political pluralism to entrench ethnicity as the fulcrum of political power, which is the salience of ethnicity in politics, and used it to incite co-ethnics against other communities and to canvass for political support during electioneering. Politicians instrumentalized ethnicity as a springboard to political power.

\section{Ethnicity in Kenyan Politics}

Kenya's politics cannot be understood without understanding Kenyan ethnicity. Before expounding further, let me clarify my use of ethnicity. I choose ethnicity over tribalism because of the reductive connotation that tribes and tribalism denote. It is a term that has been used only to refer to African ethnic groups. For example, I argue that the term tribe, which is a social construct, was used by the British imperialists to orient the Kenyan people as primordial and primitive in their divide and rule racist colonial ideologies. I therefore choose ethnicity as a more acceptable term that grants dignity to the Kenyan populace and the entire African people. In 
using the concept, I take note of the most popular view that African societies are characterized by deep ethnic cleavages that are ancient and permanent. In this view, ethnicity is viewed as irrational and primordial, which I contest is in reference to tribalism and not ethnicity. There is nothing wrong with belonging to or identifying with an ethnic extraction, since it is a form of identification with a group of people sharing common consciousness based on language and culture, but there is everything wrong with tribalism as a practice. The second view and use of ethnicity, which I strongly embrace, is that it is a social construct and a moving target.

Political activity in Kenya is centered on the construction of ethnicity, ethnic mobilization, and polarization (Ajulu,2002). Ethnic identities are used primarily used by political elites to mobilize citizen support and are rationally (or rather irrationally) embraced by the people. Ethnic politics transcends other forms of political identities such as party affiliations, issues, and discourses. Lonsdale (1992) notes that ethnicity "is not, and never was, the primordial constant but an arena of conflict" (p. 3). It is ethnicity that forms the fulcrum of both national and local politics in Kenya (Kanyinga, 2014). In electoral competition, ethnicity is used by political elites to marshall political power, get a seat at the table, and access economic resources. The elites invoke the rhetoric of access to resources for the benefit of their communities to mobilize their kin in competitions with other ethnic groups, but at the end of the day the common people do not gain anything.

Kenya comprises many ethnic groups, whose actual number is difficult to obtain given the fluid nature of these identities. However, estimates from various sources, including the census, show that the country has about 44 ethnic groups (Kanyinga, 2014). Based on census results, the major groups are Kikuyu (18\%), Luhya (14\%), Kalenjin (13\%), Luo (10\%), and Kamba, (9\%). The ethnicization of Kenya's politics means these ethnicities control most the 
state power from the executive, public appointments to the parliament. However, since no single ethnic group is numerically large enough to dominate the rest, they are forced to form ethnic coalitions to ascend to power. This has been the case since the start of self-governance in 1963 (Ajulu, 2002).

Historical perspective. Long before and even after the British imperial activities in Kenya, Kenya's different ethnic groups enjoyed peaceful co-existence reflected in intermarriages and trade (Klopp, 2013). Conflict, when it occurred, was a consequence of sharing resources such as water and grazing. As the British, by bullet, occupied more land and controlled resources, they started discriminating based on ethnicities leading to the emergence of "tribes". They started pitting ethnic groups against each other, while allocating more resources to the allies (Lynch, 2007). It was as a result of administrative expedience on the part of the colonialists. This new way of differentiating among communities, and especially the perception that some tribes were discriminated against, triggered grievances and animosity that still exists even today. This explains why one's ethnicity is still a strong form of identity in Kenya today. "What is your tribe?" Is a question that is on the tip of the tongue when Kenyans introduce each other.

As indigenous Kenyan political parties emerged in the 1950s, the links between ethnicity and politics could be clearly identified. The political elites took advantage of the ethnic grievances to mobilize support from their ethnic groups (Lynch, 2008). The Kenya African National Union (KANU) was started to defend the interests of the Kalenjin, Maasai, Turkana, and, Samburu whereas Kenya African Democratic Union (KADU) aimed to protect the larger Luo and Kikuyu ethnic groups. When Kenya attained self-rule in 1963, KANU took over and ruled until 2002. The change of power from KANU to National Rainbow Coalition (NARC) was 
viewed as a chance for Kenyans to right their wrongs, politically. However, leading up to the 2007 general elections, Kenya was sliding back to negative ethnicity characterized by erosion of civic nationhood. Ethnic tensions were palpable between the supporters of the leading presidential candidates, President Mwai Kibaki and the opposition leader Raila Odinga. These tensions led to the infamous post-election violence that rocked Kenya following the announcement of results in January 2008. As a result, over 1000 people lost their lives and close 200,000 people were displaced from their homes.

Lonsdale (2004) postulates that since the founding of multiparty politics in 1992 in Kenya, ethnicity has replaced political ideology and or class as a sense of political organization. In the Kenyan case, ethnic loyalty has more influence than national identity and classes, especially during electioneering. This explains the commonplace contention that, out of all the four presidents Kenya has had, three come from the Kikuyu ethnic group and one is from the Kalenjin group (Mukhongo, 2009), making the other ethnicities feel neglected. There is, Mukhongo argues, a perception that these two ethnic groups during their "tenure" have enjoyed immense political and economic privileges. This perception is used by politicians to incite other ethnicities against these two and hence bring them together to topple the dominance.

Even though ethnic politics continue to entrench marginalization, disenfranchisement, corruption, and conflict, as experienced in 2008, Kenyans continue to propagate negative ethnicity. The Daily Nation (2017) notes, "Historically speaking, political parties have never really divorced themselves from ethnic affiliations."

The seminal question in this study, therefore, is what is the relationship between the consumption of the Kenyan media with the political culture exhibited by the Kenyan people? 
Providing a substantial answer to this question requires an exploration of the media's effects on and relationship with politics.

\section{Media in Kenya and its Evolving Relationship with Politics}

The Kenyan mass media have grown exponentially from the $19^{\text {th }}$ century archaic systems based solely on oral communication to the $21^{\text {st }}$ century, sophisticated TV networks, radio stations, print media, and digital media. Kenya has made great strides in liberalizing its mass media sector in tandem with prevailing spirit of pluralistic politics adopted after the wave of political pluralism that swept through Kenya in the early 1990s.

The advent of political pluralism the 1990s in Kenya ushered a ray of hope for the media industry. Independent, privately-owned media outlets mushroomed and concentrated largely on political coverage (Kanyinga, 2009). Prior to the wave of political pluralism, democratization, and media liberalization, both government and independent media were heavily censored and thus served as government mouthpiece. Dissent was criminalized and there were frequent open clampdowns on critical press (Kanyinga, 2009). The leading newspapers at the time, The Daily Nation and The Standard, were deemed as tools for political subversion by the government. However, the unavoidable media liberalization witnessed in the 1990s led to a media boom, characterized by establishment of more TV stations to counter the monopoly of the airwaves by the Kenya Broadcasting Corporation (KBC), a government-owned TV and Radio station seen as a government propaganda tool (Mukhongo, 2009). KBC was "biased and tended to sanitize government views and actions" (Amutabi, 2013, p. 12). However, the monopoly ended when the Kenya Television Network (KTN) emerged as the alternative platform in the Kenyan airwaves; it permeated the media market, and was embraced by Kenyans. More and more broadcast media stations cropped up for television and radio, such as Royal Media (Citizen TV and Radio, 
Chamngei Radio, Mulembe Radio, Ramogi Radio, Hot 96 Radio, and Musyi Radio), Radio Africa (Capital TV and Radio, Radio Jambo, and Kiss TV), Media Max (K24 TV and Milele Radio), Nation Media Group (NTV, Daily Nation Newspaper, Taifa Leo, and Capital FM Radio), Standard Group (KTN, Radio Maisha, and Standard Daily Newspaper) (Amutabi, 2013).

Amutabi (2013) argues that in span of only 20 years, the Kenyan media landscape changed forever to be one of the most vibrant independent media to the envy of other East African countries and the entire African continent. Consequently, the Kenyan mass media have played critical roles in civic engagement, political accountability, and the promotion of good governance (Amutabi, 2013).

\section{Media Effects on and Relationship with Politics}

The news media are a critical player in the modern world, particularly in democratic societies. The proliferation of news media in modern society has had a heuristic impact leading to numerous studies examining its influence on and association with politics.

\section{Civic and Political Engagement}

Putnam (1995) examined the cultivation effects of television viewing by investigating the relationship between media use and civic and political engagement. He argued that television viewing is the leading cause of civic ills, including decreased social trust, lack of public interest, and low participation in politics. He notes:

There is reason to believe that deep-seated technological trends are radically privatizing, and individualizing, our use of leisure time, and thus disrupting many opportunities for social capital formation. The most obvious and probably the most powerful instrument of this revolution is television. (p. 75) 
Putnam's view is based on the belief that the time spent watching television replaces the time that would have been otherwise used to interact with other members of the community. This conclusion is often referred to as a time-replacement effect. Heavy TV viewers, it has been claimed, have a weaker sense of belonging to a specific community and exhibit limited political efficacy in changing their prevailing conditions (Putnam, 2000).

Lee (2005) also found that European TV use was associated with lower political participation. According to Lee, "Those who expose themselves to non-news television are preoccupied with consumer culture and thus spend their free time discussing the newest iPod and surfing Amazon.com, rather than reading the latest article on FactCheck.org" (p. 23). The media serves as a source of information and the marketplace of ideas and also an agent of political socialization. McLeod and Donald (1985), in an investigation of the relationship between voter turnout and the media, posit that exposure and attention to hard news in the print media are associated with voter turnout and other forms of participation. Other studies have demonstrated that the use of TV for either entertainment or information may lead to divergent outcomes regarding political participation. While the use of mass media for information is associated with higher levels of participation, the opposite is true for entertainment use (Putnam, 2000). Similarly, Newton (1999) found that watching films leads to decreased level of political knowledge and political interest which has a direct impact on political participation. Consistent with this is Holbert, Shah and Kwak's (2003) study, which concluded that movies and soaps (i.e. entertainment programs) do not influence political efficacy, interest, and participation.

On the other hand, some argue that the political news from television and newspapers encourage civic and political involvement (Hooghe, 2002; Price \& Cappella, 2002). "Television transferred politics to the living room" and as such, has contributed to an expansion of audience 
for political news thus increasing political knowledge, interest, and participation (Gurevith, Colemen, \& Blumler, 2009, p. 166).

\section{Public Trust in Government}

Some scholars have also looked at the relationship between exposure to news media and public's trust in the government. Avery (2009) notes, "Media's negativity, incivility, and lack of substance have led to growing public distrust in government" (p. 2). This is what Robinson (1976) refers to as 'Videomalaise', which he argues is the television's ability to instigate political cynicism. Robinson argues that the negativity and conflict found in the news makes the public to be less trusting of the government. However, Norris (1996) holds an opposite view, and posits that the modern ease of access to the media, and the variety thereof, promotes public trust in the government. Further, she notes that people who are generally interested in politics will seek out political news to acquire information and hence learn more about government and politics. Thus, people who are normally politically engaged and trusting of government will seek even more media, a move that will further strengthen their trust in government. On the other hand, those who are cynical of politics and, therefore, less engaged, will choose to avoid any potential influence and hence ignore the news media altogether. This leads to the question of whether media have a positive or negative relationship with and influence on political trust. These stark contrasts in opinion-based research call for further research on this topic. Thus, the purpose of this study is to help fill this gap.

\section{Patriotism}

Lin (2009) notes that during the Iraqi war, the Pentagon gave journalists the permission to report about the war while on the ground with the troops. As a result, the public received 24/7 news reporting about the invasion. During the pre-war period, according to Lin, the public 
cautiously supported the war. However, "once the war started in 2003, public support grew very fast, and patriotic fervor took over" (p. 1). Lin also argues that the rallying calls through and by the media produced patriotic feelings as well as allegiance toward the country and its flag. Additionally, Lin posits that, by playing the cheerleading role during the war with more pro-war views and little anti-war news, the media became a powerful force in pushing the rallying cry to all Americans. The scholar also postulates that the Bush Administration helped build the media's agenda, and the media, in turn, helped build the public's agenda to the point where most Americans rallied to support the war in early 2003. This shows how the media can cultivate love and support for one's country and its initiatives.

Other than media's coverage of war, scholars have investigated the role mediated sports can play in promoting nationalized fervor. Billings, Brown, and Brown (2015) studied the potential role of nationalism in the 2012 London Olympics, finding that people who were heavy viewers of the 2012 London Olympics were more likely to exhibit higher levels of nationalism, patriotism, and smugness than light viewers of Olympic media.

\section{Negative Ethnicity}

In Kenya racial bias is hardly an issue because the country is racially homogeneous, but ethnic bias and nepotism take the place of racial bias. According to Oyugi (1997), the news media fanned tribal animosity and hatred which led to the infamous inter-ethnic wars termed post-election violence witnessed in 2008 in Kenya. Vernacular radio stations were criticized for broadcasting hateful narratives that promoted ethnic bigotry. He further argues that Kenyan politicians and tribal warmongers spread negative rhetoric through the media and exploited the fragile ethnic tensions that exploded, leading to Kenyans butchering each other. Gīthīnji and Holmquist (2012) also document that the mainstream media took sides during political 
campaigns giving prominence to news stories with total disregard to journalistic ethical and professional standards.

\section{Summary}

Current research illustrates that the media's relationship with and influence on political attitudes and behaviors points to at least two directions: First, some scholars argue that the ultimate association between the media and its influence on political participation, trust, and national pride varies depending on the 'form' of the media because different forms of the media serve different functions (Shah, Kwak, Holbert, 2001). For example, Television viewing (Putnam, 2000) and Internet use have been indicated as the major causes of civic and political inactivity, whereas newspaper reading has been found to increase political interest and thus political participation and trust (Norris, 2000). The second direction that research demonstrates is the influence of the media content, with suggestions that different content exert different influences on political behaviors and attitudes. For instance, while watching science fiction and reality shows on TV diverts people from social interactions and thus makes them politically passive, long hours spent watching public affairs news on TV have been found to enhance political participation (Norris, 1996). In addition, some studies indicate that watching situational comedies has negative effects on local political participation (Shah, et al., 2001). These studies illustrate that indeed, the media regardless of the form or the content, have an influence on political attitudes and consequently political behaviors of its consumers. 


\section{Research Questions}

Research demonstrates that there are many variables under political culture that can be explored. While all these variables could be examined, this study seeks to explore only four of these variables (patriotism, trust, ethnicity, and political participation) and their relationship with consuming the media.

According to Almond and Verba (1963), political trust and interest are essential antecedents for political participation as it influences people's reaction to public affairs and perceived political legitimacy of governments. Researchers continue to debate whether the media have positive or negative relationships and impact on political engagement. The controversy is whether the media serve as a mobilizing force by informing the public about why, how, and where the public should and can involve themselves in political processes hence leading to a politically active citizenry (Norris, 1996; 2000) or whether the media are the cause of a declining social capital and subsequently, reduced political participation as argued by Putnam (2000). Thus, the divergence in opinions on the relationship between and impact of the media on political participation begets the following question;

RQ1: What is the relationship between media consumption and political participation in Kenya?

Previous literature documents that the media, through a barrage of negative coverage, undermines public confidence in a political system, politicians, and political institutions and thus promotes political cynicism. However, some scholars also assert that the media can instill public confidence in political processes. Norris (1996) posits that attention to news is positively and strongly associated with political knowledge which translates to increased participation as a well as political trust in the government. Thus, a question is posed; 
RQ2: In what ways, if any, is media consumption associated with political trust in Kenya?

Previous studies, particularly in America, demonstrate that the media through the coverage of sports and war can promote patriotic feelings and attitudes. Lin (2009) argues that the U.S. mainstream media played a key role in marshalling public support toward the Iraqi war. Additionally, Billings, Brown, and Brown (2015) assert that people who watched the 2012 Olympics showed greater support and allegiance to the stars and stripes. Thus,

RQ3: What is the relationship between media consumption and national pride among Kenyans?

Kenya is a multi-ethnic country with over 40 ethnic groups. Ethnicity is at the nerve of Kenya's polity as a means of gaining political support. Some researchers argue that the media in Kenya have been a conduit of hate speech and consequently, are used to incite one ethnic group against the other (Amutabi, 2013). Thus,

RQ4: Is there any relationship between media consumption and inter-ethnic attitudes among Kenyans?

\section{Conclusion}

Overall, the purpose of this chapter was to summarize the existing literature and provide a basis for the research questions and hypothesis posed. Scholars have documented that political culture, operationalized as the orientations people hold toward a political system, varies across the world. This study has summarized the American political culture which has been extensively documented by political communicators and scientists as well as intercultural scholars. The reviewed literature also 'travelled south' and documented the existing political culture in Latin America. In addition, political cultures of two Asian countries, China and Singapore, two 
economic giants in the eastern hemisphere which empirically mirror each other, have been reviewed. Aspersions have been cast on Africa as 'the dark continent' due to the paucity of studies conducted in and about this vast continent. But this study seeks to provide an illumination of the political culture in a specific African country, Kenya, and thus a review of the African political culture and particularly, the Kenyan culture have been provided. Lastly, the relationship between media exposure and its impact on political attitude formation and subsequent political behaviors have been demonstrated through the summary of political communication research. This chapter has demonstrated how a variety of mass communication factors may impact political culture, leading to some specific research questions. The next chapter describes the methods the researcher will use in answering those research questions. 


\section{CHAPTER III: METHOD}

The previous chapter established the theoretical grounding for the current study with a review of current literature on the conceptualization of political culture, the American political culture, political culture in Latin America, Asia, Africa, and finally, Kenya's political culture. Since the current study examines the relationship between media use and political culture in Kenya, current research on the relationship between media consumption and political attitudes and behaviors, conceptualized in this study as political culture, were also documented. This chapter explains the process of data collection and analysis.

\section{Participants}

To test the perceived influence of the news media on the political attitudes and behaviors in Kenya, operationalized herein as the Kenyan political culture, I use survey data collected from 206 Kenyans. In total, 320 Kenyans filled out the online questionnaire. However, only 206 participants satisfactorily completed the survey. The survey target population consists of $76.7 \%$ Male, $22.8 \%$ Female, with $0.5 \%$ choosing not to disclose their gender. Of those surveyed, $79.9 \%$ identified as Native Kenyans (meaning they are born of native Kenyan parents), $0.5 \%$ as multiracial; $14.7 \%$ did not wish to disclose their identity, with $4.9 \%$ choosing other. The most frequent level of education achieved by the participants is a bachelor's degree at $66 \%$, followed by a master's degree (17\%), a diploma (associate degree, 12.1\%), high school (2.9\%), and $\mathrm{PhD}$ (1.9\%). The average age of the participants was 29.05 years, ranging from 19 years old to 47 years old.

Since the study investigates the relationship between media consumption and political attitudes and behaviors in Kenya, categorical data was collected about the forms of media consumed by the participants. Most of the participants reported accessing their news via the 
Internet $(n=141,68.4 \%)$, followed by Television $(n=52,25.2 \%)$, Newspapers $(n=10,4.9 \%)$, Radio $(n=2,1 \%)$, and lastly, interpersonal interactions $(n=1,0.5 \%)$.

\section{Sampling Procedure}

After attaining approval from the Institutional Research Board (IRB), I sent emails, Facebook posts, and messages, and primarily, WhatsApp messages requesting Kenyans to participate in the study by following the link to a university-hosted webpage attached to the invitation message. I combined criterion and snowball sampling methods to ensure that the participants were only Kenyans over the age of 18, who resided in Kenya, and not within the European Economic Area. Upon clicking the link, the participants were directed to the informed consent message where they would voluntary choose to participate in the study or decline. All participants were requested to complete the survey and then forward it to other Kenyans. In this way, a snowball sampling technique was utilized. All the respondents gave informed consent, were notified that they could stop taking the survey at any time, and were assured that their responses would remain anonymous. Moreover, I informed the participants that my study was investigating their media consumption habits and political attitudes and behaviors.

\section{Measures}

\section{Media Consumption}

To measure the participant's media consumption, comprised of the respondent's recollection of media use habits, a 9-item scale obtained from the 2000 National Annenberg Election Survey and modified to suit this study's research design was used. Media consumption was measured following four distinct dimensions: watching the news on TV, reading newspaper articles, listening to the news on the radio, and reviewing news on the Internet. 
TV news consumption. To obtain participant's consumption of news from thes TV, the following questions were posed: "On a normal day, how much time do you spend watching the news on TV, reading a daily newspaper, listening to radio shows, reading news online?" Responses to this item were coded on 8-point nominal levels where $1=$ No time, $2=$ Less than 15 minutes, $3=15-30$ minutes, $4=30$ minutes- 1 hour, $5=1-3$ hours, $6=3-6$ hours, $7=6-12$ hours, $8=$ more than 12 hours. Then, respondents were asked to report how much attention they paid specifically to TV news: "How many days in a week do you watch news on TV? This item was coded as follows; $1=$ One, $2=$ Two, 3 -Three, $4=$ Four, $5=$ Five, $6=$ Six, $7=$ Seven.

Newspaper consumption. For newspaper article consumption, the following question was asked: "How many days in a week do you read a daily newspaper?" This item was also coded in a similar fashion; 1=One, 2=Two, 3-Three, 4=Four, 5=Five, 6=Six, 7=Seven.

Radio news consumption. For consumption of news through the radio, respondents were asked; "How many days in a week do you listen to radio shows that invite listeners to call in to discuss current events, public issues or politics?" This item was coded as follows: $1=$ One, 2=Two, 3-Three, 4=Four, 5=Five, 6=Six, 7=Seven.

Online news consumption. A single item was also used to measure the respondents' attention to and consumption of news from the Internet. They were asked, "How many days in a week do you read political news stories online?" Similar coding scheme was followed.

To measure participant's general attention to news across media platforms, an additional 4-item Likert-type scale ( $1=$ Strongly Agree, $7=$ Strongly Disagree) was incorporated. The participants were asked to report the extent to which they agreed with the following statements: (a) It's a regular part of my day to catch up with the news, (b) I follow the news to understand what's going on in the world, (c) I follow the news to know what other people are talking about, 
(d) It's my duty to keep up with what's going on in the world, and (e) I have a pretty good understanding of the main issues facing our country.

\section{Political Interest and Participation}

First, respondents were asked to report their interest in politics by answering a 6-item scale, with questions such as "How interested would you say you are in politics?" The response alternatives were $1=$ Very interested, $2=$ Somewhat interested, $3=$ Not very interested, 4=Not at all interested, and 5= Don't know. Secondly, the participants were asked about their political affiliation: "On political matters, people often talk about NASA (National Super Alliance and Jubilee). Generally, how would you place/identify your political affiliation?” Participants answered this question using a 5-point Likert-type scale with responses including 1=NASA, 2=Jubilee, 3=Independent, 4= Other (specify), 5=Don’t know. To measure the participants' levels of political participation, 4 items were used. Past and future participation in politics were investigated by asking the respondents to indicate their responses to the following question:

The following are political actions people can take. Please indicate whether you have participated in any of these actions, whether you might do it, or would never, under any circumstances, do it: Signing petitions, joining in boycotts, attending lawful demonstrations, joining unofficial strikes, and voting.

The response alternatives included; $1=$ Have done it, $2=$ Might do it, 3=Never done it, 4=Would never do it, 5=Don’t know. Similarly, the respondents were asked, “As of now, how likely are you to vote in future elections (for example, by-elections or 2022 general elections)?" The answers ranged from $1=$ Very Likely to $5=$ Not at all. 


\section{Political Trust}

Political trust is a composite of 16 items all measuring the levels of confidence or trust Kenyans have in various political institutions. For instance, to measure trust in government in Nairobi, respondents were asked, "Thinking of the national government, how much of the time do you think you can trust the government to do the right thing?" Responses were coded on a 5item Likert-type scale with responses ranging from 1=Always to $5=$ Don't know. The levels of trust Kenyans have in various institutions were measured. These institutions include the churches, the armed forces, labor unions, police, political parties, parliament, civil service, presidency, Supreme Court, elected officials, and even prospective political candidates.

Previous research indicates that there is a growing distrust in the media by the public, which could mean or lead to a lack of willingness to exert effort to seek and obtain knowledge about national news and political information through the media (Cappella \& Jamieson, 1996) Thus, one's trust in the media to report the news fairly could have an impact on whether or not an individual consumes information via the media at all, or even which type of the media an individual consumes the most. Therefore, to measure the level of confidence Kenyans have on the Kenyan media, the following question was posed: "How much of the time can you trust the media to report the news fairly?" with options being 1= Always, $2=$ Frequently, $3=$ Occasionally, 4=Rarely, 5=Never.

\section{Patriotism}

The levels of love for Kenya as reported by Kenyans was captured using the Patriotism scale developed by Livingstone and Markham (2008) and used by Billings, Brown, and BrownDevlin (2015). The scale measured the degree to which the participant agreed or disagreed with 6 
items provided, such as "I love my country," and "I am very proud to be from my country", with the response alternatives ranging from 1= Strongly Disagree to 5=Strongly Agree.

\section{Ethnic Attitudes}

The attitude of Kenyans toward members of other ethnicities was measured using the Perceived Realism Scale (PRS) adopted and modified from a study by Punyanunt-Carter (2008) on television viewers' perceived realism perceptions of African Americans portrayals on television. In the present study, African Americans were replaced with other ethnicities since Kenya is a multi-ethnic society and is largely racially homogeneous. The items on this scale included items such as "The media present negative attributes about other ethnicities as they really are in life," and "If I see other ethnicities on the media as untrustworthy, selfish, proud, ignorant, I can't be really sure they are really that way." Responses were solicited using a 5point, Likert-type scale with responses ranging from 5=Strongly Disagree to $1=$ Strongly Agree.

\section{Data Analysis}

Data collected were analyzed quantitatively using the IBM Statistical Package for Social Sciences statistics (SPSS-25). The data analysis process was conducted in a two-step systematic fashion. First, scale reliability analyses were conducted for all the scales to ascertain the consistency of participant responses. All the reliability tests and subsequent coefficients are reported in the next chapter.

To answer all four research questions, a series of Pearson's product-moment correlations analyses were conducted to examine the relationships between media consumption and political participation, political trust, patriotism, and inter-ethnic attitudes. 


\section{Conclusion}

This chapter has presented the procedures that were followed in this study. First, the participants have been described in terms of descriptive statistics and the procedure followed

during their recruitment. Second, the sampling procedure has been explained. Third, the chapter has also presented the measures used to capture the participants' responses, and finally, the process of data analysis has been described. The next chapter presents the results of the study. 


\section{CHAPTER IV: RESULTS}

The previous chapter described the participants whose responses informed this chapter, the procedures followed in their recruitment, the measures used, and the process followed in analyzing the data. This chapter presents the results of the data analysis.

\section{Scale Reliabilities}

Reliability coefficients were calculated for all the variables present in the study with multiple items. The political interest measures adopted from the 2000 National Annenberg Election Survey had an alpha coefficient of .75, indicating a respectable reliability (Wrench, Thomas-Maddox, Richmond, \& McCroskey, 2013). Political participation measure adopted from the same survey obtained a Cronbach's alpha $=.82$. Political trust measure obtained a Cronbach's alpha $=.87$. Livingstone and Markham's (2008) Patriotism Scale obtained a Cronbach's alpha $=.96$, indicating an excellent reliability according to Wrench, ThomasMaddox, Richmond, \& McCroskey (2013). Lastly, the Perceived Realism Scale adopted from Punyanunt-Carter (2008) had a reliability coefficient $=.81$ considered to be acceptable level of reliability.

\section{Pearson Product-Moment Correlations}

During the bivariate analyses, I examined the relationships between media consumption and patriotism, political participation, political trust, and inter-ethnic attitudes.

First, research question one asked if there is any relationship between media consumption and political participation in Kenya. A Pearson product-moment correlation revealed that online news consumption was negatively correlated with political participation, $r(203)=-.27, p<.001$. Similarly, political interest, which is a strong predictor of political participation, was found to be negatively correlated with online news consumption, $r(203)=-.37, p<.001$. In addition, 
political interest was negatively correlated with the number of hours spent watching TV, $r(204)$ $=-.187, p<.001$. There were no significant correlations found between political participation and listening to radio, or reading newspapers. However, it is important to note that a positive relationship was found between political interest and political participation, $r(203)=.29, p<$ .001 . These are significant findings for reasons which will be explained in the discussion.

Research question two asked if there is any association between media consumption and political trust in Kenya. A Pearson product-moment correlation conducted detected no significant relationship between media consumption and political trust in Kenya.

Research question three asked whether there is a relationship between media consumption and national pride among Kenyans. A Pearson-product moment correlation revealed no significant relationship between media consumption and patriotism in Kenya.

Lastly, research question four asked if there is a relationship between media consumption and inter-ethnic attitudes among Kenyans. Similar findings were drawn; that is, there was no significant relationship found between media consumption and inter-ethnic attitudes among Kenyans. See Table 1. 
Table 1. Pearson Product-Moment Correlations for Media Consumption and Patriotism, Political Trust, Political Participation and Inter-Ethnic Attitudes

\begin{tabular}{|c|c|c|c|c|c|c|c|c|c|c|c|}
\hline Variables & $\begin{array}{l}\text { Pearson } \\
\text { Correlation }\end{array}$ & $\begin{array}{l}\text { Watching } \\
\text { TV-hours }\end{array}$ & $\begin{array}{l}\text { Watching } \\
\text { TV-Days }\end{array}$ & $\begin{array}{l}\text { News } \\
\text { papers }\end{array}$ & Radio & Online & Patriotism & $\begin{array}{c}\text { Political } \\
\text { participation }\end{array}$ & $\begin{array}{c}\text { Ethnic } \\
\text { attitudes }\end{array}$ & $\begin{array}{c}\text { Political } \\
\text { Trust }\end{array}$ & $\begin{array}{l}\text { Political } \\
\text { Interest }\end{array}$ \\
\hline $\begin{array}{l}\text { Watching } \\
\text { TV-hours }\end{array}$ & $\begin{array}{l}\text { Pearson } \\
\text { Correlation }\end{array}$ & 1 & & & & & & & & & \\
\hline $\begin{array}{l}\text { Watching } \\
\text { TV-Days }\end{array}$ & $\begin{array}{l}\text { Pearson } \\
\text { Correlation }\end{array}$ & $.197 * *$ & 1 & & & & & & & & \\
\hline Newspapers & $\begin{array}{l}\text { Pearson } \\
\text { Correlation }\end{array}$ & -.082 & .023 & 1 & & & & & & & \\
\hline Radio & $\begin{array}{l}\text { Pearson } \\
\text { Correlation }\end{array}$ & -.077 & .072 & $.205^{* *}$ & 1 & & & & & & \\
\hline Online & $\begin{array}{l}\text { Pearson } \\
\text { Correlation }\end{array}$ & $.222 * *$ & $.150 *$ & .047 & .129 & 1 & & & & & \\
\hline $\begin{array}{l}\text { Political } \\
\text { participation }\end{array}$ & $\begin{array}{l}\text { Pearson } \\
\text { Correlation }\end{array}$ & -.073 & .120 & -.050 & -.056 & $-.273 * *$ & .058 & 1 & & & \\
\hline $\begin{array}{l}\text { Ethnic } \\
\text { attitudes }\end{array}$ & $\begin{array}{l}\text { Pearson } \\
\text { Correlation }\end{array}$ & -.017 & -.002 & .051 & .086 & .013 & $-.270 * *$ & -.038 & 1 & & \\
\hline $\begin{array}{l}\text { Political } \\
\text { Trust }\end{array}$ & $\begin{array}{l}\text { Pearson } \\
\text { Correlation }\end{array}$ & -.060 & -.066 & .052 & .076 & .066 & $.315^{* *}$ & -.082 & $-.292 * *$ & 1 & \\
\hline $\begin{array}{l}\text { Political } \\
\text { Interest } \\
\end{array}$ & $\begin{array}{l}\text { Pearson } \\
\text { Correlation }\end{array}$ & $-.187 * *$ & -.066 & .064 & .023 & $-.373 * *$ & -.070 & $.293 * *$ & -.075 & .106 & 1 \\
\hline
\end{tabular}

${ }^{* *}$. Correlation is significant at the 0.01 level (2-tailed). ${ }^{*}$. Correlation is significant at the 0.05 level (2-tailed). 


\section{Conclusion}

This chapter has presented the results obtained from the survey and subsequent scale reliability tests and correlations between the variables in the study. The next chapter will draw conclusions based on these results, the theoretical, methodological, and practical implications in to political communication research and practice while highlighting the limitations of the study. Lastly, suggestions for future studies will be made. Taken together, the results show (a) a negative correlation between online media consumption, political interest, and participation, (b) a negative association between TV viewing and political interest, which is a strong predictor of political participation, (c) no correlations between media consumption through TV viewing, newspaper reading, listening to radio and patriotism, political trust, and inter-ethnic attitudes. These results are discussed in the next chapter. 


\section{CHAPTER V: DISCUSSION}

Kenya's political culture is well documented in the literature (Mukhongo, 2009: Shilaho, 2018). However, the relationship between the prevailing political attitudes and behaviors (political culture) and self-reported media use habits in Kenya remains understudied. As such, the purpose of this study is to investigate, explain, and thus, address a major limitation in understanding Kenya's political culture, namely the relationship and the perceived influence of the Kenyan media on Kenya's political culture. This study examines the relationship between media consumption and the various variables that form a nation's political culture within the framework of media effects theories. While previous conceptualizations of political culture include several aspects, this study concentrates on four major dimensions of political culture (a) political interest and participation, (b) political trust, (c) patriotism, and (c) inter-ethnic attitudes in Kenya.

I asked questions to establish the relationship between the media consumption habits by Kenyans and the various aspects of political culture. To conclusively answer the research questions posed, I conducted Pearson product-moment correlations.

\section{Summary of Findings}

\section{Research Question One}

The first research question asked if there is any relationship between media consumption and political participation in Kenya. Results revealed a negative correlation between online media consumption and political participation in Kenya. This revelation adds to the debate on the socio-political consequences of Internet use. Some technologists and social critics surmise that Internet users become increasingly removed from meaningful social relationships and less likely to be active politically and in the community as they spend more time online (Shah, 
Shmeirbach, Hawkins, Espino, \& Donovan, 2002). These are the people who use the Internet for recreational purpose (Shah et al.). On the other side of the spectrum, some research suggests that those using the Internet for information, especially political information, exhibit higher levels of political efficacy, knowledge, interest, and participation (Kenski \& Stroud, 2006). This study supports the former pessimistic view, that frequent Internet use by Kenyans could be associated with people's withdrawal from political life.

The negative association between media consumption and political participation also advances the argument by Lee (2005) that "those who expose themselves to non-news television are preoccupied with consumer culture and thus spend their free time discussing the newest iPod and surfing Amazon.com, rather than reading the latest article on FactCheck.org” (p. 23). It also aligns with the time displacement hypothesis by Robert Putnam (2000). According to Putnam, television is the scapegoat for the declining political participation across the world and, specifically, in America. Putnam argues that watching television drives down political participation because the time spent watching television would otherwise be devoted to interactions with other members of the community, discussions, and deliberations which could spur political engagement. However, the negative correlation in Kenya does not support the argument by some scholars who contend that media use has a positive relationship with and influence on civic and political participation (Boulianne, 2009; Xenos \& Moy, 2007).

This finding seems to imply that the proliferation of Internet connectivity has permeated and altered almost all aspects of human life, and this apparently includes political life. By virtue of this medium (the Internet), a new picture of politics is being drawn in Kenya, especially in terms of political participation. Most of the sampled Kenyans reported accessing news via the 
Internet, and, based on the findings, this widespread Internet use in Kenya seems to herald a new political culture, that of a politically disengaged and disinterested citizenry.

While there was no significant correlation found between watching television and political participation in Kenya, it was interesting to discover that there is a negative correlation between watching television and political interest as well as political interest and online news consumption. Norris (1996) argues that interest in politics is a strong predictor of political participation. The two negative associations point to a possibility that the more Kenyans consume news online and by watching TV, the less interested they would be politically. However, these could also be a segment of the society that are generally politically disinterested. It is plausible to argue that those who are generally politically interested and engaged would pay close attention to the news and, therefore, learn more about government and politics and even participate more. The negative correlation between online news consumption and political interest supports the conclusion by Xenos and Moy (2007) that Internet use and political participation are contingent upon political interest as a key factor, hence the positive correlation between political interest and participation, which supports Norris' earlier assertion.

Another set of scholars argue that the Internet has a positive association with and influence on political engagement. They posit that the Internet activates those citizens who are generally predisposed and interested in politics (Polat, 2005); the Internet provides more convenient ways of being politically engaged (for example, signing petitions) and mobilizes politically inactive people (Krueger, 2002). They conclude that the Internet, reinvigorates civic life by increasing access to political information, facilitating political discussion, and offering an alternative venue for political expression, and engagement. The findings in Kenya do not support this position. 
There was no significant relationship found between newspaper reading, listening to radio, and political participation. This finding seems to counter Norris's (1996) contention that exposure to hard news in the newspaper and radio have a strong positive correlation with political interest and consequently, political participation as well as trust in public figures and institutions. Lee and Wei (2008) found that a decrease in newspaper reading among baby boomers and generation $\mathrm{Y}$ is associated with their decreasing political participation. They note that there has been a decline in political participation through signing petitions, attending rallies to voting in America. Young American's political involvement has declined the most precipitously (Lee \& Wei, 2008). Ali and Fatima (2016) who found that newspaper reading among Pakistani youth, which together with the Internet are the most preferred medium of information seeking, are strongly and positively correlated with their political awareness, knowledge, interest, and participation, which explains the healthy democratic system in Pakistan. Similarly, among the British, newspaper reading and listening to radio was positively correlated with voting (Livingstone and Markham, 2008). Livingstone and Markham found that active and sustained engagement with the news through the papers makes the British people more likely to vote. Extrapolated to the Kenyan context, the findings do not support the arguments by these studies.

More recently, country level-voting rates in some African countries are positively correlated with listening to radio, while people who listen to radio news frequently are more likely to vote (Kuenzi \& Lambright, 2010). This study does not support this conclusion by Kuenzi and Lambright. A possible explanation for the lack of correlation between newspaper use, listening to radio, and political participation in Kenya could be that these are just unique theoretical constructs without any significant relationship or exposure to news in the papers and 
the radio do not influence Kenyans positively or negatively in their political participation behaviors. Future research should explore conclusively the prevalence of newspaper readership (or lack of it) among Kenyans to determine whether there has been a decline or an increase in their newspaper readership culture and listening to radio even thought this study did not find any relationship with political participation.

There has been an increasing disdain toward the media the world over. Public confidence in the press has seen the steepest decline (Cooke \& Gronke, 2007). Media bias is at the top of the public's complaints toward the media. I argue that it is possible that the same can be said of the Kenyan press and perhaps Kenyans are aware of the influence that the newspaper and radio have and do not want to succumb to it.

\section{Research Question Two}

The second research question asked if there is a relationship between media consumption and political trust in Kenya. Past research is inconclusive on whether media use has any significant relationship and influence on trust in the government, politicians, and public institutions. This is because there are two polar-opposite arguments over the relationship between media use and political trust. Some researchers argue that the media have a negative relationship with and effect on trust, while others posit that the relationship between media exposure and public trust is positive and reciprocal. Robinson (1976) suggests that distrust in government is closely related to and could be a result of media's incivility, negativity, and lack of substance. He calls this "Videomalaise". He further argues that television, specifically, has an ability to instigate political cynicism through a barrage of negativism and, thus, to eat away the trust that the public has in the government and politicians to solve societal issues. Norris (1996) makes an opposite claim and proposes the "virtuous circle". She argues that the ease with which 
people can access and the availability of a variety of media available to the public engender political trust.

With such dramatically different conclusions, what does the current study reveal about political trust in Kenya? The findings do not support either thesis, as there was no significant relationship found between political trust and media use in Kenya.

\section{Research Question Three}

The third research question asked whether there is any relationship between media consumption and national pride among Kenyans. There was no association found between media use and patriotism among Kenyans. This could possibly indicate two things. First, Kenyans just love their country regardless of the amount of media they consume. This is demonstrated by a mean of 4.16 on a five-point scale with higher scores translating to high patriotic fervor. Second, even if the media were to only highlight stories that promote negativity and despair or even positive stories about the country, regardless of coverage, Kenyans would not flinch in their love for the red, green, black, and white colors of the flag. In other words, these two variables, media consumption and patriotism, are unique theoretical constructs that do not seem to have a significant relationship, at least in the Kenyan case.

Some past research offers conflicting conclusions on whether media consumption is correlated with and influences nationalistic attitudes and qualities. For instance, Lin (2009) conducted a study on Americans' consumption of news about the Iraqi war and noted heightened patriotic values and feelings during that time. Billings, Brown, and Brown-Devlin (2015), on the other hand, conducted a somewhat similar study regarding Americans' consumption of Olympic media and their nationalistic attitudes and feelings. They noted that "Olympic media consumption does not seem to have a relationship with nationalism nearly as much" (p. 16). The 
Kenyan case does not support either direction. However, going by the study conducted by Billings et al. (2015), future studies should explore the specific content that Kenyans watch on television, read on newspapers, listen to on the radio, and consume online for any significant relationships with their levels of nationhood.

\section{Research Question Four}

Research question four asked if there is any relationship between media consumption and inter-ethnic attitudes among Kenyans. There was no significant relationship found between media use habits and attitudes among and toward Kenyans of different ethnicities. RQ3 was posed because past research shows Kenya's politics is founded based on ethnic mobilization and polarization. One cannot understand Kenya's political sphere without first an appreciation of the role played by ethnic identity and association (Mohamed, 2017; Mukhongo, 2009). Most Kenyans often support a candidate from their own ethnic extraction because they trust him or her. Mohamed (2017) reported in an Aljazeera newspaper article that "almost all the voters who spoke to Al Jazeera in the Kenyan capital, Nairobi, said they are voting for candidates from their own ethnic extraction out of 'fear' of someone other than their own taking office and lack of 'trust' in candidates from other ethnic groups." In addition, "ethnic politics is of relevance to Kenya's politicians who, together with the intelligentsia, instrumentalize ethnicity in contestation for political power and economic opportunities" (Shilaho, 2018, p. 2).

Ethnicity transcends national issues and class interests in Kenya. I, therefore, questioned whether it could be that Kenyans do not trust political candidates from other ethnic groups and, therefore, are apprehensive to vote for them based on their perceptions due to portrayals in the media. While there was sufficient theoretical reason to ask whether there was any association between Kenyans' media use habits and their attitudes towards other ethnicities, no significant 
relationship in either direction was found. Past research (Ajulu, 2002; Kanyinga, 2014;

Mukhongo, 2009) demonstrate that ethnicity is salient in Kenyan politics, it is the fulcrum of political power. Kenyans have been socialized since independence to believe that the most significant consideration for political office is a candidate's ethnicity. Ostensibly, Kenyans have embraced political rhetoric that electing one of their own guarantees state resources and better opportunities. Therefore, I argue that the lack of significant association between media use and inter-ethnic attitudes could be due to the entrenched distrust in ethnic outgroups as a result of illiteracy, high trust in politicians, and prejudice and is not necessarily due to the portrayals of these ethnic groups by the media which the public consume. Regardless of the media consumption by Kenyans, which may positively or negatively portray other ethnic groups, Kenyans will still favor co-ethnic politicians thus perpetuating the politicization of ethnicity in Kenya.

Interestingly, inter-ethnic attitudes were negatively correlated with political trust. This finding seems to suggest that the perceptions Kenyans have of other ethnic groups may not necessarily be influenced by the media, since media consumption (in all its forms) did not have a relationship with inter-ethnic attitudes, but they (Kenyans) inherently do not trust people from other ethnic groups such as politicians. This confirms the report by Mohamed (2017) suggesting the entrenched distrust among and toward different ethnicities, in matters of politics, in Kenya. On this issue, future research should explore more closely the effects that a specific media form (particularly radio or TV) or content (e.g., comedies) and channels have on inter-ethnic attitudes and behaviors portrayed by Kenyans. In addition, there are widespread vernacular radio and TV stations in the country that provide a treasure trove of opportunities for future research into the 
relationships and potential impacts of consuming content from such stations on the attitudes toward other Kenyan ethnicities.

\section{Implications}

The findings from this study have theoretical and methodological implications that may help guide further research on media effects and political communication. In addition, practical implications for the political communication and media industry, particularly in Kenya, will be noted.

\section{Theoretical Implications}

Theoretically, this study expands political communication and media effects research into a different, under-researched context, Kenya. The relationship between and the impact of media consumption and political attitudes and behaviors have been a matter of recurrent concern in communication research. However, most of these studies have been largely conducted in the west, with very little to none exploring these relationships and effects in the continent of Africa, and more specifically, in Kenya. Thus, this study helps to illuminate the media's relationship with political attitudes and behaviors in a different context, with results revealing interesting yet unique associations.

First, the present study revealed that online media consumption was negatively correlated with political interest and political participation, which is consistent with the argument that online media use encourages increased isolation and exclusion from other aspects of life, political life included (Shah, Shmeirbach, Hawkins, Espino, \& Donovan, 2002). However, the finding counters the suggestion by some researchers that there is no relationship between online news consumption and political participation (Kenski \& Stroud, 2006). The study provided strong theoretical support to Shah et al.'s (2002) argument that there is indeed a relationship 
between online media consumption and political behaviors, albeit a negative relationship, and this time, in Kenya.

Sweeping arguments have been made by different researchers about the relationship between television viewing and political participation. Putnam (2000) blames the advent of television and the amount of time spent watching television as the sole cause for an increasingly politically disengaged public. Norris (1996) however, in a reply to Putnam, argues that the attack on television as the sole cause of social ills ranging from violence among children to racism, illiteracy, alienation, lack of civic, and political engagement is unfounded. Despite the pervasiveness of television use in modern families, the relationship between watching television and political participation is more complex than suggested (Norris,1996). The finding in this study, which shows no significant correlation between watching television and political participation, does not provide theoretical support in either direction, on whether it is a complex relationship (Norris, 1996) or straightforward relationship as Putnam (2000) posits. This calls for further replication studies to fully make certain the conclusion of this study.

The results related to the relationship between watching television and political interest have some interesting theoretical implications. Despite television viewing and political participation having no direct significant relationship, political interest, which is a strong predictor of political participation (Norris, 1996), is negatively correlated with watching television. Specifically, watching television has no association with being politically engaged among Kenyans, while watching television has a negative correlation with being interested politically. This runs counter to current research: One can be politically interested and, thus, be proactive in seeking out news (probably political news), but this has no relationship with their political participation. A possible explanation could be that the relationship between watching 
television and political participation should be measured differently, perhaps by looking at the contents or specific channels and content that Kenyans watch. Based on this finding, it remains unclear what this implies for the general claims on the relationship and impact of television on political behaviors (interest and participation).

Given that modern-day television industry affords its viewers an array of programs from which to choose, future research should go beyond measuring media consumption solely based on time spent on a specific medium and investigate the relationships between watching specific programs on TV such as sitcoms, political news, current affairs, and reality TV shows, and political attitudes and behaviors. In addition, future studies should look at the motives for which Kenyans seek out the media, especially TV. Here, the future research should answer the following questions: How do Kenyans seek to fulfill their information or entertainment needs? And consequently, what relationship does seeking such needs have with political knowledge and interest, which influence political participation and other political behaviors? Lastly, not just the types of programs but also the TV stations and or channels being watched should be explored. Such research, then, would likely use a uses and gratifications perspective to better understand Kenyan media use.

I have called for further research to add to the uses and gratifications perspectives in political media effects, but I also suggest that this study adds to the expansive uses and gratifications research which contends that the audience are active seekers of media content in multiple forms to satisfy their informational, entertainment, escapism, and social interaction needs (Diddi \& La Rose, 2006). Some studies support a positive relationship between media use (especially social media, TV, and newspaper use) and forms of political and civic involvement, claiming that the use of these media for informational, relational, and expressive purposes have 
the potential to trigger political engagement (Chen, Chan \& Lee, 2016; Chen, 2017; Chen \& Chan, 2017). For example, Chan, Wu, Hao, Xi, and Jin (2012) demonstrates that individuals who are motivated to seek out information on politics and current affairs online tend to be more politically and civically engaged. In the same vein, some other scholars suggest that informationseeking motives are positively associated with individual's likelihood to be involved politically (Zhao, Lin, Liu \&Yang, 2013). The findings from Kenya point to an opposite direction; online media consumption (speculatively for recreational purposes) does not engender political activity but instead seems to encourage passivity and lack of interest in politics. Future research should investigate the motives behind accessing and consuming the media in relation to Kenyans' political attitudes and behaviors.

The media's relationship with political trust has been understood either in terms of Robinson's (1976) videomalaise or Norris' (1996) virtuous circle hypotheses. The former blames the media as the cause of distrust in government while the later counters Videomalaise with the premise that the ease of accessibility and variety of media forms and content engender political trust. This study supports neither of the hypotheses. However, more studies should be conducted in future to determine any limiting factors that could have led to the current conclusion.

On media consumption and patriotism, this study did not find any significant relationship. A possible explanation for this is that participants were not asked to report on the type of content they consumed that could foster or diminish nationalistic attitudes. Billings et al. (2015) found that when Americans watched the winter Olympics, there were no heightened patriotic feelings reported while Lin (2009) found that Americans supported the red, white, and blue more during the coverage of the Iraqi war by the American media. Thus, future studies in Kenya should 
explore the specific media content being selected and consumed in relation to the patriotic feelings harbored by Kenyans.

Lastly, there was no significant relationship between media use and inter-ethnic attitudes in Kenya. This finding does not seem to support Oyugi’s (1997) argument that the Kenyan media have been sowing seeds of disharmony and discord among Kenyans. However, it is important to note that Gīthīnji and Holmquist (2012) suggest that the Kenyan media have been biased in their coverage particularly on political hot-topics, thus propagating distrust among different ethnicities in Kenya. This could be a possible explanation for the negative correlation between inter-ethnic attitudes and political trust in Kenya. Media's impact on, rather than relationship with, perceptions of other ethnicities should be investigated in future. This may provide clearer explanations as to whether Kenyans consume the media with preconceived notions and preconceptions about other ethnicities, and thus, seek a reinforcement of the same from the media or the media influences the initial formation of stereotypes and attitudes.

The negative correlations between online media consumption, watching television with political interest and participation seems to engender a parochial-subject political culture in Kenya. This type of political culture is described by Almond and Verba (1963) as one characterized by passive citizenry who have low political efficacy, low political interest, and limited political participation.

\section{Methodological Implications}

This study drew its findings from those who could mainly access social media (Facebook and WhatsApp) and emails, which were the primary means of survey distribution. Hence, when interpreting the political behaviors and attitudes in relationship with media exposure in Kenya which are constitutive knowledge of Kenya's political culture, one should be aware of this 
limitation. Consequently, a big sample of Kenya's populace that could not access social media was left out which draws in the knowledge-gap hypothesis. According to the knowledge-gap hypothesis, when mediated information enters a social system, it leads to an increase in the existing knowledge gap between those of a higher and lower social economic status (Eveland, Dietram, \& Scheufele, 2000). The hypothesis presumes that there is an initial existence of a gap in knowledge between the "haves" and "have nots" in the society. It, therefore, follows that the Kenyans who completed the survey could be from relatively higher economic status who could afford to access the internet and are more knowledgeable politically while those who could not access social media may potentially be from lower economic status without the ability to access the internet, and are possibly less politically informed. The net effect of this "deprivation of knowledge" may lead to deprivation of ability to contribute to such studies, low political efficacy, knowledge, participation, and even political power. This speculation is something that future studies should investigate conclusively.

Moreover, a "one-shot" study like this might not have thoroughly captured and explained the relationship between media consumption and political behaviors and attitudes. If one were to conduct a longitudinal study, it is possible that causal explanations could be provided, providing the ability to better explain the influence of media use on Kenya's political culture. Further work is needed to gain a better understanding of the relational and causal dynamics between the various variables in the study.

Another methodological drawback in the study is the scales used. While the scales were borrowed from existing surveys and reworded to fit the current study, it is possible that this created some confusion in the respondents, which would provide a possible explanation for the low reliabilities reported in some of the scales. 
This study explored the salience of ethnicity in Kenya's political culture and its relationship with the media use habits of the Kenyan people. However, I did not explicitly address the ethnic extraction of the respondents in relation to their political trust, interest in politics, and participation. Past research shows that Kenyans often vote for a political candidate from a similar ethnic background because of the supposed trust in the candidate to fight for and protect their interests. It, therefore, follows that this will influence their perception of politicians from ethnic outgroups and the likelihood to participate in political life. Kenyans are more likely to turn out in large numbers to vote for co-ethnic politicians and vice-versa. I theorized that perhaps the Kenyan media socializes the masses with political cynicism toward other ethnic groups. This was partly supported by the negative correlation between ethnic attitudes and political trust. However, since I did not find any significant relationship between media use and inter-ethnic perceptions, future research should explore the case and effect dynamics between the media, ethnicity, political interest, and participation.

Finally, this study did not investigate the role of media content. Media consumption was just measured based on the time spent watching television in hours and days, time spent online reading news, time listening to radio, and time spent reading newspapers. Future studies should examine more specifically the content such as sitcoms, reality TV shows, political podcasts, debates, talks shows, and political news and how these genres relate with political behaviors and attitudes. This is because the modern television market is saturated with content that could have a relationship with and impact on politics. 


\section{Practical Implications}

Despite the methodological drawbacks noted above, the study's findings have some notable practical implications for Kenya's media industry, media and communication scholars, and the political communication industry in Kenya.

First, media are a key component for a functioning democratic political system. They play an integral and crucial role in informing the masses and being government watchdogs. If indeed, the media (such as the Internet and watching TV) in their role do not engender a proactive citizenry, politically, to what extent then are the media fulfilling their role as agents in the growth of the Kenyan democracy?

The relationship between media consumption and certain political behaviors and attitudes is well documented. This study found that online media consumption is negatively correlated with political participation and political trust. Additionally, watching television is negatively correlated with political interest. Lower political interest will certainly have an impact on political participation. These findings should worry a growing democracy like Kenya. If the citizens continue to be politically cynical, they will most likely be politically passive. With a citizenry that is relatively young and politically lethargic, the country's future would seem bleak. Also, it seems that the Kenyan media played into the Videomalaise theory of being uncivil, negative, and biased thus explain the cynical Kenyan populace. Journalists should re-evaluate their role in entrenching this attitudes and behaviors.

Political strategists, communicators, and media experts can glean a lot from this study. First, while the findings that online media use was negatively correlated with political participation, and political interest, as well as the negative correlation between watching television with political interest, this should not be interpreted as a validation of the power of the 
Internet and the Kenyan television. Rather, one should be careful to note that media use is selfselected. Kenyans who are generally politically disinterested and disengaged will most likely find political news unappealing and may remain politically passive. However, the fact that most Kenyans reported accessing news via the Internet provides a possible resource for political strategists and campaigners to reach out to this important block of the citizenry especially as the world witnesses the immense impact of Twittersphere and Facebook rhetoric. Ostensibly, not all Kenyans are politically passive, and thus, could political activism through the more commonly used electronic and social media could tilt the scales in a democratic process.

\section{Conclusion}

I believe this study has contributed to a better understanding of the relationship between media consumption and political culture in Kenya. A country's political culture is an outcome of shared political values, political attitudes, and behaviors. This study has established that the media, particularly the Internet and television, have a negative association with political participation and political interest in Kenya. Political participation is the hallmark of democracy; it is the means through which a country can grow and develop and through which people can voice their concerns and exercise their constitutional rights. The media clearly have an integral role in the growth and strengthening of a democracy. Perhaps future studies will authoritatively opine on this matter; for now, they seem to be discouraging participation, while encouraging passivity.

To sum up, while this study investigated the relational dynamics between media use and political attitudes that constitute Kenya's political culture, the news media and the Internet should not by any means be labelled the sole cause or even the major culprit for the problems 
reported. The responsibility for the political ills could stem from other areas and players who have a "joint custody of democracy" who must share the blame. 


\section{REFERENCES}

Ajulu, R. (2002). Politicized Ethnicity. Competitive politics and conflict in African studies, 61(1), 251-268.

Ali, R., \& Fatima, A. (2016). Social media, newspapers and political awareness of youth in Pakistan. Pakistan Library \& Information Science Journal, 47(1), 30-41.

Almond, G., \& Verba, S. (1963). The Civic Culture. Princeton: Princeton University Press.

Amutabi, M. N. (2013). Media boom in Kenya and celebrity galore. Journal of African Cultural Studies, 25(1), 14-29. doi:10.1080/13696815.2013.7653

Arce, M. (2003). Political violence and presidential approval in Peru. Journal of Politics, 65(2), $72-83$.

Avery, J. (2009.) Videomalaise or virtuous circle? The influence of the news media on political trust. International Journal of Press/Politics,4(4), 27-44

Baldwin, J. R., Faulkner, S. L., Hecht, M. L., \& Lindsley, S. L. (Eds.). (2006). Redefining culture: Perspectives across the disciplines. Mahwah, NJ: Lawrence Erlbaum Associates

Barnett, G.A. (1988). Communication and organizational culture. In G.M. Goldhaber \& G.A. Barnett (Eds.) Handbook of organizational communication (pp.101-130). Norwood, NJ: Ablex.

Basedau, M. \& Stroh, A. (2007): Ethnicity as a determinant of party preference and voting behavior in francophone Africa. Unpublished conference paper prepared for the 4th ECPR General Conference, Pisa, 06.-08.09.2007.

Bennett, W. L. (1980) Public Opinion in American Politics. New York, NY: Harcourt Brace Jovanovich 
Billings, A., Brown, K., \& Brown-Devlin, N. (2015). Sports draped in the American flag: Impact of the 2014 winter Olympic telecast on nationalized attitudes. Mass Communication \& Society, 18(4), 377-398. doi.10.1080/15205436.2014.995767

Bobo, L. \& Dawson, M. (2009). A change has come: Race, politics, and the path to the Obama presidency. W.E.B. Du Bios Institute for Africa and African American Research

Booth, J. \& Richard, P. (2011). Economic crisis and political attitudes in Latin America and the Caribbean. A paper presented during the Midwest Political Science Association Congress, Chicago, Illinois

Boulianne, S. (2009). Does internet use affect engagement: A meta-analysis of research. Political Communication, 26(2),193-211.

Bratton, M., \& Kimenyi, M. S. (2008). Voting in Kenya: Putting ethnicity in perspective. Journal of Eastern African Studies, 2(2), 272-289. doi $10.1080 / 17531050802058401$

Call, C. T. (2008). The fallacy of the 'Failed State'. Third World Quarterly, 29(8), 1491-1507.

Carlson, E. (2015). Ethnic voting and accountability: A choice experiment in Uganda. World Politics, 67, 353-385.

Cebula, R., Payne, J., \& Saltz, I. (2017). Determinants of geographic voter participation rate differentials: The 2014 mid-term election. Atlantic Economic Journal, 45(1), 35. doi.org/10.1007/s11293-016-9525-3

Chang, P. (2015). In Xi Jinping's crackdown on civil society, even women's rights activists aren’t spared. South China Morning Post. Retrieved from http://www.scmp.com/ comment/insight-opinion/article/1739150/xi-jinpings-crackdown-civil-society-evenwomensrights 
Chan, M., Wu, X., Hao, Y., Xi, R. \& Jin, T. (2012). Microblogging, online expression, and political efficacy among young Chinese citizens: The moderating role of information and entertainment needs in the use of Weibo. Cyberpsychology, Behavior, and Social Networking, (15), 345-349.

Chan, J.M. (1994). Media internationalization in China: Processes and tensions. Journal of Communication, 44, 70-88.

Chia, Y. T. (2016). Singapore general election 2015 and the role of citizenship education. The Round Table, 105(2), 149-160. doi.org/10.1080/00358533.2016.1154382

Chew, J. (1988) Moral education in a Singapore secondary school. Unpublished Doctoral Dissertation, Monash University.

Chen, Y. (2017). WeChat use among Chinese college students: exploring gratifications and political engagement in China. Journal of International and Intercultural Communication, (10)1, 25-43.

Chen, Z. \& Chan, M. (2017). Motivations for social media use and impact on political participation in China: A cognitive and communication mediation approach. Cyberpsychology, Behavior, and Social Networking, 20(2), 83-90.

Chen, H.T., Chan, M. \& Lee, F. L. (2016). Social media use and democratic engagement: a comparative study of Hong Kong, Taiwan, and Chin. Chinese Journal of Communication, (9), 348-366.

Crook, R. C. (1997). Winning coalitions and ethno-regional politics: The failure of the opposition in the 1990 and 1995 elections in Côte d'Ivoire. African Affairs, 96, 215-242 
Croucher, S., Otten, R., Ball, M., Grimes, T., Ainsworth, B., Begley, K., \& Corzo, L. (2013). Argumentativeness and political participation: A cross-cultural analysis in the United States and Turkey. Communication Studies, 64(1), 18-32. doi.org/10.1080/10510974.2012.727942

Cooke, T. E. \& Gronke, P. (2007). Disdaining the media: The American public's changing attitudes toward the news. Political Communication, 24, 259-281.

De Silva, F. C., Clark, T., \& Vieira, M.B. (2015). Political culture. The International Encyclopedia of Political Communication. doi: 10.1002/9781118541555.wbiepc161

Democracy clings on in a cold economic climate (2002, August 15). The Economist. Retrieved from https://www.economist.com/the-americas/2002/08/15/democracy-clings-on-in-acold-economic-climate

Diddi, A. \& LaRose, R. (2010). Getting hooked on news: Uses and gratifications and the formation of news habits among college students in an internet environment. Journal of Broadcasting and Electronic media, 50, 193-210.

Elazar, D. J. (1994). The American Mosaic. Boulder, CO: WesTView Press

Encarnación, O. G. (2003). The strange persistence of Latin American democracy. World Policy Journal, 20(4), 30-40.

Eveland, W. \& Scheufele, A.D. (2000). Connecting news media use with gaps in knowledge and participation. Political Communication, 17, 215-237.

Garrido, M. (2017). Why the poor support populism: The politics of sincerity in Metro Manila. American Journal of Sociology, 123(3), 647-685. doi-10.1086/694076

Gīthīnji, M., \& Holmquist, F. (2012). Reform and political impunity in Kenya: Transparency without accountability. African Studies Review, 55, 53-74. doi:10.1353/arw.2012.0006 
Gudykunst, W. B., \& Ting-Toomey S. (1988). Culture and interpersonal communication. Newbury Park, CA: Sage.

Gurevith, M., Coleman, S. \& Blumler, J. (2009). Political communication: Old and new media relationships. The ANNALS of the American Academy of Political and Social Science, 625(1), 15-39.

Holbert, R. L., Shah D. V., \& Kwak, N. (2003). Political implications of prime-time drama and sitcom use: Genres of representation and opinions concerning women's rights. Journal of Communication, 53, 45-60.

Hooghe, M. (2002). Watching television and civic engagement. Disentangling and effects of time, programs, and stations. Harvard International Journal of Press? Politics, 7, 84-104.

Hunter, J. D. \& Bowman, C. (1996). The State of disunion. Charlottesville, VA: Educational Foundation

Inglehart, R. (1988). The Renaissance of Political Culture. American Political Science Review, 82, 1203-1230

Ipsos Synnovate (n.d.). Trust in public institutions. Kenya. Retrieved from https://www.ipsos.com/ipsos-mori/en-uk/trust-public-institutions

Kanyinga, K. (2014). Kenya: Democracy and political participation. Nairobi, NRB: Open Society Initiative for Eastern Africa.

Kanyinga, K. (2009) The legacy of the white highlands: Land rights, ethnicity, and post-2007 election violence in Kenya. Journal of Contemporary African Studies 27(3): 325-344.

Kenski, K. \& Stroud, N. J. (2006). Connections between Internet use and political efficacy, knowledge, and participation. Journal of Broadcasting and Electronic Media, 50(2), 173192. 
Kluver, R. (2014). Political culture and information technology in the 2001 Singapore general election. Political Communication, 21, 435-458, doi: 10.1080/10584600490518333

Klopp, J. (2013). Ethnic clashes and winning elections: The case of Kenya's electoral despotism. Canadian Journal of African Studies, 35, 473-517.

Koonings, K. \& Kruijt, D. (2003). Latin American political armies in the twenty-first century. Bulletin of Latin American Research,3, 371-384

Kroeber, A. L., \& Kluckholm, C. (1952). Culture: A critical review of conceptions and definitions. Cambridge, MA: Harvard University Press.

Krueger, B. (2002). Assessing the potential of Internet political participation in the United States. American Politics Research, 30, 476-498.

Kuenzi, M. \& Lambright, G. (2010). Voter turnout in Africa? An examination of electoral participation in 10 African countries. Party Politics, 17, 767-799.

Lee, T. (2005). Media effects on political disengagement revisited: A multiple-media approach. Journalism \& Mass Communication Quarterly, 2(82), 416-433

Lee, T \& Wei, L. (2008). How newspaper readership affects political participation. Newspaper Research Journal, 29(3).

Li, L. (2004). Political trust in rural China. Modern China, 30(2), 228-258.

Lin, C. A. (2009). Selective news exposure, personal values, and support for the Iraq war Communication Quarterly, 57(1), 18-34

Livingstone, S. \& Markham, T. (2008). The contribution of media consumption to civic participation. The British Journal of Sociology, 59(2), 77-112.

Lonsdale, J. (1992). The political culture in Kenya. The Royal African Society, 87-108 
Lynch, G. (2007). Negotiating ethnicity: Identity politics in contemporary Kenya. Review of African Political Economy, 33(107), 49-65.

McClosky, H. \& Zaller, J. (1987). The American ethos. Cambridge, MA: Harvard University Press.

McCombs, M. E. \& Shaw. D L. (1972). The agenda-setting function of mass media. The Public Opinion Quarterly, 2, 176-187

McLaughlin, Eric S. (2007): Beyond the racial census. The political salience of ethnolinguistic cleavages in South Africa. Comparative Political Studies,40(4), 435-456

McLeod, J. M., \& McDonald, D. (1985). Beyond simple exposure: Media orientations and their impact on political process. Communication Research, 12, 3-33.

Miller, N. \& Yeager, R. (1994): The quest for prosperity. Boulder, CO. WesTView.

Mitchell, A. S. (2000). Toward a model of democratic stability: Political culture in Central America. Estudios interdisciplinarios de América Latina y el Caribe,11(2): 5-29.

Moemeka, A. (1996). Interpersonal communication in communalistic societies in Africa. In W. Gudykunst, S. Ting-Toomey, \& N. Tsukada (Eds.), Personal communication across cultures (197-214). Thousand Oaks, CA: Sage.

Mohamed, H. (2017, August 6). Kenyan elections: The ethnicity factor. Aljazeera. Retrieved from https://www.aljazeera.com/indepth/features/2017/08/kenyan-elections-ethnicityfactor-170806081143385.html

Mukhongo, L.L. (2009). The Kenyan media: confronting state terror and atrocities. Journal of communication and Language Arts, 3(1), 26-43.

Mutalib, H. (2000). Illiberal democracy and the future of opposition in Singapore. Third World Quality, 21(2), 313-342. 
Kenya National Bureau of Statistics (2016, March 18). Leading economic indicators. Retrieved from https://www.knbs.or.ke/inflation/

Newton, K. (1999) Mass media effects: Mobilization or media malaise? British Journal of Political Science. (29), 577-599.

Norris, P. (1996). Does television erode social capital? A reply to Putnam. Political Science and Politics, 29(3), 474-480.

Norris, P. (2000). A virtuous circle. Political communications in postindustrial societies. Cambridge: Cambridge University Press

Nwosu, P. (2005). Understanding African conceptualization of intercultural competence. In Deardorff, Darla K. (Eds.) (2009) The Sage handbook of intercultural competence. Thousand Oaks, CA: Sage Publications

Ong, T.C., (1979). Report on Moral Education. Singapore: Ministry of Education.

Oyugi, W. (1997). Ethnicity in the electoral process: The 1992 general elections in Kenya. African Journal of Political Science, 2(1), 41-69.

Oyugi, W., Wanyande, P. \& Odhiambo-Mbai, C. (2008). The Politics of transition in Kenya: From KANU to NARC. Nairobi: Heinrich Böll Foundation.

Pew research center for the people and the press. (2009). Values Survey. Washington, DC: Pew Research Center

Polat, R. K. (2005). Internet and political participation. European Journal of Communication, 20, 435-459.

Price, V. \& Capella, J. N. (2002). Online deliberation and its influence. The electronic dialogue project in campaign 2000. IT \& Society, 1, 303-329. 
Putnam, R. D. (1995). Bowling alone: America's declining social capital. Journal of democracy, 6(1). 65-78

Putnam, R. D. (2000). Bowling alone: The collapse and revival of American community. New York, NY: Touchstone.

Rae, P. (2001). Review of theater and the politics of culture in contemporary Singapore. Arts Magazine, 83-88.

Robinson, M. J. (1976). Public affairs television and the growth of political malaise. American Political Science Review,70, 409-432.

Salinas, E. \& Booth, J. (2011). Miro-social and contextual sources of democratic attitudes in Latin America. Journal of politics in Latin America, 3(1), 29-64.

Salinas, E. \& John, A. B. (2009). Contextual and micro-social sources of democratic norms in Latin America. Paper presented at the Midwest Conference of Latin American Studies, Dallas, Texas, 20 November.

Sanders, K. (2009). Communicating politics in the twenty-first century. New York, NY: Palgrave Macmillan

Schlozman, K. L., Verba, S., \& Brady, H. E. (1999). Civic participation and the equality problem. In T. Skocpol \& M. P. Fiorina (Eds.), Civic engagement in American democracy (427-460). Washington, DC: Brookings Institution Press.

Shah, D.V., Kwak, N. \& Holbert, R. L. (2001). Connecting and disconnecting with civic life: Patterns of Internet use and production of social capital. Political Communication, 18, $141-162$. 
Shah, D.V., Shmeirbach, M.G., Hawkins, J., Espino, R., \& Donovan, J. (2002). Non-recursive models of Internet use and community engagement: Questioning whether time spent online erodes social capital. Journalism and Mass Communication Quarterly, 79, 964987.

Shilaho, W.K. (2018). Political power and tribalism in Kenya. Cham, Switzerland: Palgrave Macmillan.

Sullivan, J. L., Piereson, J. \& Marcus, G. E. (1982). Political tolerance and American democracy. Chicago: University of Chicago Press.

Swedlow, B. (2011). Editor's introduction: Cultural theory's contributions to political science. Political Science \& Politics, 44 (4), 703-10.

Twaweza East Africa (2017, June 12). Constitution, devolution, and inclusion: Citizen's views on governance in Kenya. Retrieved from https://www.twaweza.org/go/szw-governance2017-ke.

Ugur, M. (2014). Corruption's direct effects on per-capita income growth: A meta-Analysis. Journal of Economic Surveys, 28(3): 472-490

Welsh, B. (2015) Singapore swing. New Mandala. Retrieved from http://asiapacific.anu.edu.au/newmandala/2015/09/12/singa pore-swing

Wilson, R. W. (1997). American political culture in comparative perspective. Political Psychology, 18(2), 483-502.

World values survey (2010). Wave 6. Retrieved from http://www.worldvaluessurvey.org/WVSDocumentationWV6.jsp

Wrench, J., Thomas-Maddox C., \& Richmond, V. P. (2012). Quantitative research methods for communication: A hands-on approach. Buffalo, New Yok: Oxford University Press. 
Xenos, M. \& Moy, P. (2007). Direct and differential effects of the internet on political and civic engagement. Journal of Communication, 57(4), doi.org/10.1111/j.14602466.2007.00364.x

Yengoyan, A. A. (1989). Culture and ideology in contemporary Southeast Asian Societies. Unpublished manuscript. Environment and Policy Institute, East-West Center, Honolulu, Hawaii.

Zechmesiter, E. (2014). (Ed). The political culture of Democracy in the Americas: Democratic governance across 10 years of the Americas Barometer. US-Aid, US: Vanderbilt University

Zhao, M., Lin, J., Liu, Y., \& Yang, L. (2013). The effects of Weibo use on political trust and social trust among college students in mainland China. Paper presented at the IAMCR 2013 Conference Dublin, June 25-29. 


\section{APPENDIX A: EMAIL INVITATION}

Dear Prospective Participant,

I am a graduate student in the School of Communication at Illinois State University and as part of a Master's thesis, I am conducting a study about people's news media consumption. To participate, you must be over the age of 18, Kenyan citizen, or lived in Kenya for at least 15 years. You must not be currently residing in the European Economic Area (EEA).

Your participation is completely voluntary, and anything you answer in the survey will remain completely anonymous. There is no penalty for choosing not to participate in this study. Furthermore, you have the right to decline to answer any question or withdraw from the study at any time without penalty or adversely affecting your relationship with Gilbert, Dr. Baldwin, or Illinois State University.

If you would like to take the survey, please go to this link:

https://illinoisstate.az1.qualtrics.com/jfe/form/SV_dm4yBrfnmOahxuBIf you have any questions, please contact Gilbert Kipkoech by email at gkipkoe@ilstu.edu.

Thank you for your time and consideration.

Gilbert Kipkoech

Graduate Student/Graduate Teaching Assistant

School of Communication

Illinois State University

United States 


\section{APPENDIX B: INFORMED CONSENT}

\section{INFORMED CONSENT TO PARTICIPATE IN A RESEARCH STUDY}

\section{Dear Participant,}

I am a graduate student under the direction of Dr. John Baldwin in the School of Communication at Illinois State University. I am inviting you to participate in a research study to understand how the media (re) produces political cultures (political attitudes and behaviors) as part of my master's Thesis. Findings in the form of statistics across surveys may be used for poster presentations, conference papers, or possible publication.

I am inviting your participation, which will involve an online survey on your media use and political attitudes and behaviors. The survey should take approximately 15-20 minutes.

Your participation in this study is voluntary. If you choose not to participate or to withdraw from the study at any time, there will be no penalty (it will not affect your relationship with Gilbert Kipkoech, Dr. John Baldwin, or Illinois State University). You can refuse to answer any question you do not wish to answer. Your responses are completely anonymous. To ensure your anonymity, we will not reveal anything else that identifies any participant or track your IP address.

We believe there are minimal risks associated with participating in this project beyond those experienced in everyday life. You will receive no compensation for this study and there is no anticipated benefit for you as a participant. Your participation will help extend our understanding of the media influences on political attitudes and behaviors thus cultivating or developing a political culture.

Your signature below indicates that you are voluntarily making a decision to participate in this research study and have read and understood the information presented above. You may 
print a copy of this consent form to keep. Please note that you are NOT eligible to participate if you are currently within the European Economic Area.

Please direct any questions and/or comments to Dr. John Baldwin (jrbaldw@ilstu.edu) or to me (gkipkoe@ilstu.edu). For questions regarding your rights as a research participant you are encouraged to contact the Illinois State University Research Ethics and Compliance Office:

Phone: 309-438-5527, Email: rec@ilstu.edu.

Respectfully,

Gilbert Kipkoech

Graduate Student

Illinois State University, School of Communication

gkipkoe@ilstu.edu

Do you agree to participate?

_ Yes, I am at least 18 and agree to participate

_ No, I do not wish to participate, or I am not 18 


\section{APPENDIX C: SURVEY INSTRUMENT}

The following section asks about your media consumption, by this I mean the amount of time you take to access/read/listen to/watch news.

1. Which news media is your most preferred source of political information?
a) $\mathrm{TV}$
b) Radio
c) Newspaper
d) Internet
e) Interpersonal interaction

2. On a normal day, how much time do you spend watching the news on TV, listening to the news on the radio, reading a newspaper and/or reading news online?
a) $1=$ no time
b) $2=$ less than 15 minutes
c) $3=15-30$ minutes
d) $4=30$ mins -1 hour
e) $5=1-3$ hours
f) $6=3-6$ hours
g) $7=6-12$ hours
h) $8=$ more than 12 hours

3. How many days in a week do you watch the news on TV? (by this I mean, the 7 p.m. news i.e. Citizen Tv's Nipashe, NTV Jioni, KTN Leo, K24's Mchipuko wa Habari or the 9 p.m. prime-time news on Citizen TV, KTN News, NTV, 24 or KBC)
a) One
b) Two
c) Three
d) Four
e) Five
f) $\mathrm{Six}$
g) Seven

4. How many days in a week do you read a daily newspaper?
a) One
g) Seven
b) Twice
c) Three
d) Four
e) Five
f) $\mathrm{Six}$

5. How many days in a week do you listen to radio shows that invite listeners to call in to discuss current events, public issues or politics?
a) One
g) Seven
b) Twice
c) Three
d) Four
e) Five 
f) $\mathrm{Six}$

6. How many days in a week do you read political news stories online?
g) One
g) Seven
h) Twice
i) Three
j) Four
k) Five
1) $\mathrm{Six}$

7. During the past week, how much attention did you pay to news stories about politics?
a) A great deal
b) Some
c) Not too much
d) None
e) Don't know

The following questions ask about your interest and participation in politics. Please indicate the level that best describes your interest and participation in politics.

8. How interested would you say you are in politics?
a) Very interested
b) Somewhat interested
c) Not very interested
d) Not at all interested
e) Don't know

9. On political matters, people talk a lot about NASA (National Super Alliance) and Jubilee. Generally, how would you place/identify your political affiliation?
a) NASA
b) Jubilee
c) Independent
d) Other (please specify
e) Do not wish to disclose

10. The following are some different forms of political action that people can take. Please indicate whether you have participated in any of these actions, whether you might do it, or would never, under any circumstances, do it.

$\begin{array}{ccccc}\text { Have done } & \text { Might do } & \text { Never done } & \text { Would never } & \text { Don't } \\ \text { it } & \text { it } & \text { it } & \text { it } & \text { know }\end{array}$
a) Signing a petition
12
3
a) Joining in boycotts
12
b) Attending lawful demonstrations
12
3
3

$\begin{array}{ll}4 & 5 \\ 4 & 5 \\ 4 & 5\end{array}$




$\begin{array}{llllll}\text { c) Joining unofficial strikes } & 1 & 2 & 3 & 4 & 5 \\ \text { d) Voting } & 1 & 2 & 3 & 4 & 5\end{array}$

11. Some people seem to follow what is going on in government and public affairs most of the time, whether there is an upcoming election or not. Others are not that interested. Would you say you follow what is going on in government and public affairs most of the time, some of the time, only now and then or hardly at all?
a) Most of the time
b) Some of the time
c) Now and then
d) Hardly
e) Don't know

12. How many days in the past week did you discuss politics with your family, friends, workmates or online?
a) One
b) Tow
c) Three
d) Four
e) More than four days

13. How often would you say you attend political rallies or political meetings in support of your preferred candidate?
a) Always
b) Most of the time
c) Some of the time
d) Never
e) Don't know

14. As of now, how likely are you to vote in future elections (e.g. by elections or 2022 general elections)?
Very likely
Somewhat likely
Neutral
Not Very Likely
Not at all

15. How would you rate the responsibility of voting as a Kenyan?
a) Most important
b) Very important
c) Somewhat important
d) Not too important

The following section asks you about the trust (the level of confidence) that you have in the following institutions. Please indicate the level of trust/confidence you have in the following institutions.

16. Below are several organizations. For each one, please indicate how much confidence you have in them: is it great confidence, quite a lot of confidence, not very much confidence, or none at all?

The churches A Great Deal Quite A Lot Not Very Much None At All $\mathrm{Dk}$ The armed forces

$\begin{array}{ll}1 & 2 \\ 1 & 2\end{array}$
3

4

4 
The press/media

Labor unions

$\begin{array}{ll}1 & 2 \\ 1 & 2 \\ 1 & 2 \\ 1 & 2 \\ 1 & 2 \\ 1 & 2 \\ 1 & 2\end{array}$

3

3

The police

The government in Nairobi

Political parties

Parliament

The Civil service
3

3

3

3

3

$\begin{array}{ll}4 & 9 \\ 4 & 9 \\ 4 & 9 \\ 4 & 9 \\ 4 & 9 \\ 4 & 9 \\ 4 & 9\end{array}$

17. Thinking about the national government, how much of the time do you think you can trust the government to do the right thing?
a) Always
b) Most of the time
c) Some of the time
d) Never
e) Don't know

18. How much confidence you have in the presidency (Executive Branch of the national government)?
a) A great deal
b) A fair amount
c) Not too much
d) None at all

19. How much confidence you have in the parliament?
a) A great deal
b) A fair amount
c) Not too much
d) None at all

20. How much confidence do you have in the judiciary-including the Kenyan Supreme court?
a) A great deal
b) A fair amount
c) Not too much
d) None at all

21. How much confidence do you have in the elected officials in your county?
a) A great deal
b) A fair amount
c) Not too much
d) None at all

22. To what extent do you agree/disagree with the following statements?

a) Candidates usually tell voters what they want to hear

b) Candidates usually tell the voters what they truly believe is good for the country

c) Candidates tell the voters what they will really try to do

d) Candidates cannot be trusted to keep promises they make while campaigning

23. How much of the time do you think you can trust the media to report the news fairly?

a) Always

b) Most of the time 
c) Only some of the time

d) Almost never

Directions. The following question asks about your patriotism (the love you have for and pride in your country). Please indicate from the following list that best describes your feeling.

24. How proud are you to be Kenyan?
a) Very proud
b) Quite proud
c) Not very proud
d) Not at all proud
e) I am not Kenyan

25. To what extent do you agree/disagree with the following statements?
a) I love my country.
b) I am proud to be from my country.
c) In a sense, I am emotionally attached to my country and emotionally affected by its actions.
d) Although at times I may not agree with the government, my commitment to my country always remains strong.
e) It is important to serve my country.
f) When I see my country do well in events like the Olympics, I feel great.

Directions: The following are statements people may make about television. For each statement please indicate the degree to which you agree with each statement (Strongly Agree to Strongly Disagree).

26. Television presents things as they really are in life.

27. If I see something on TV, I can't be sure it really is that way.

28. Television lets me really see how other people live.

29. TV does not show life as it really is

30. Television lets me see what happens in other places as if I were really there.

Directions: Here are some statements people may make about television. For each statement, please indicate the extent to which you agree or disagree with the statement, from strongly agree to strongly disagree.

31. The media presents negative personality characteristics about other tribes as they really are in life.

32. The media lets me really see negative personality characteristics of other tribes

33. The media presents other tribes as untrustworthy, selfish, proud, or ignorant, which they really are in real life 
34. The media presents positive personality characteristics about other tribes as they really are in life

35. If I see other tribes on the media as untrustworthy, selfish, proud or ignorant, I can't be sure that they are really that way

36. If I see other tribes the negative personality characteristics about other tribes in the media, I can't be sure their personality is really that way

37. If I see members of other tribes with positive personality characteristics, I can't be really sure they are really that way

38. If I see something in the media, I can't be sure it is really that way.

Demographic questions

39. What is your biological sex?

- Male

- Female

- Transgender

- Other

40. Please indicate your age on your last birthday

41. What is your ethnic background?

- Native Kenyan

- Asian

- Multiracial

- I don't want to disclose

- Other (please specify)

42. Please indicate your highest level of achieved so far

- High school

- Diploma

- Bachelor's or its equivalent (CPA, CPS, etc.)

- Master's

- Ph.D. 